The Politics of Ethnic Identity in Sub-Saharan Africa

\title{
Elliott Green
}

\begin{abstract}
:
Evidence suggests that African Presidents tend to target co-ethnics with patronage, especially in non-democracies. Coupled with evidence on the role of incentives in driving ethnic identity change, I propose that a change in the ethnic identity of the President should lead to an increase in the proportion of people identifying with the President's ethnic group. I use survey data from fourteen African countries with Presidential transitions to show that ethnic Presidential change leads to an upward shift in the percentage of respondents identifying with the new ruling ethnic group in non-democracies, and that this shift increases with the level of autocracy. I also show that countries where citizens perceive more ethnic favoritism see higher levels of ethnic switching. Within-survey evidence from Zambia demonstrates that this shift is immediate, and case study evidence from early modern China suggests that this phenomenon is not limited to Sub-Saharan Africa.
\end{abstract}


There now exists a large literature on how ethnicity can influence politics, especially as regards public goods distribution and conflict (Baldwin \& Huber, 2010; Franck \& Rainer, 2012; Habyarimana et al., 2009; Montalvo \& Reynal-Querol, 2005; Posner, 2004). However, very rarely has the question been asked the other way around, namely how politics can influence ethnic identity, especially in the short term. Indeed, while there is a small literature on a number of individual case studies of politically-induced identity change (Cassan, 2015; Laitin, 1998; Posner, 2005), as well as how long-term processes of industrialization and state-building can influence ethnic and national identity formation (Gellner, 2006 [1983]; Tilly, 1994; Wimmer, 2018), there remains a lacuna in the study of how contemporary political change can alter ethnic identity in a broad context.

As such I propose a theory of how a change in the ethnic identity of the President can create an incentive for citizens to switch their ethnic identity towards that of the new President, at least in non-democratic contexts. More specifically, the literature on ethnic favoritism has shown how Presidents target co-ethnics with preferred access to government employment, contracts, roads, schools and hospitals, especially in non-democracies where governments do not need to rely on a broad coalition for support and monitoring of public goods provision from the media and opposition parties is weak (Burgess et al., 2015; Franck \& Rainer, 2012; Kramon \& Posner, 2016; Young, 1976). This system of discrimination creates incentives for individuals to identify with the President's ethnic group, such that the more non-democratic the regime, the greater the incentive to switch ethnic groups. Thus, given the aforementioned literature that demonstrates the roles of political incentives in identity change, there should be evidence of identity change coinciding with ethnic presidential change in non-democracies.

To test this theory I use demographic survey data from fourteen African countries that have had ethnic presidential changes and at least two comparable surveys collecting data on ethnic identity. Africa is an ideal location to examine this theory, both because most states in the continent are ethnically diverse, thereby leading to multiple examples of ethnic 
presidential change, and because many states are non-democratic. Based on data from over half a million female respondents across 56 country surveys between 1977 and 2017 and including 25 cases of a change in the President's ethnic identity, I show that ethnic presidential change induces respondents to switch their ethnic identity towards that of the new President in non-democracies, and that this shift increases with the level of autocracy. Moreover, the size of this shift is significant: for a country with a Polity score of -5 on a scale of -10 to +10 , or a borderline autocracy, this shift is equivalent to $1.8 \%$ of the population. Given the average size of the ruling ethnic group in these countries, this result suggests that roughly one in ten people identifying with the President's ethnic group in such a country would have previously identified with another group.

As I show below, this result is robust to the use of a number of different specifications, control variables and definitions of democracy, as well as a smaller sample of male respondents. I also show that ethnic groups that are related linguistically to the President's ethnic group benefit from ethnic switching as well, and that countries where citizens perceive more ethnic favoritism in Afrobarometer surveys see a higher level of ethnic switching. Moreover, I use within-survey evidence from either side of the Zambian presidential election in 2001 to show that this shift can be immediate, which suggests that switching is done in order to obtain government favors rather than in response to previous favors. I then use survey subsamples to show that ethnic identity change is concentrated within the Presidents' home regions and among unemployed women; these findings are consistent with respondents seeking to switch their ethnic identities in order to obtain government employment and to avoid retribution after their co-ethnic President leaves office. Finally, I briefly examine case study evidence from early modern China that suggests that this phenomenon is not limited to contemporary Africa.

Theory 
The hypothesis that ethnic political change should result in mass ethnic change towards the ethnic group of the new President is built on two separate but related sets of literature, namely scholarship on ethnic favoritism and on theories of ethnic change. In the former case there is now a substantial literature on the degree to which Presidents target public and private goods such as cabinet positions, roads, and health and education spending towards their ethnic brethren (as sometimes proxied by their birthplace), particularly in Africa (Ahlerup \& Isaksson, 2015; André et al., 2018; Burgess et al., 2015; De Luca et al., 2018; Dickens, 2018; Franck \& Rainer, 2012; Francois, Rainer \& Trebbi, 2015; Hodler and Raschky, 2014; Kramon and Posner, 2016; Li, 2018). In addition there is qualitative evidence from a variety of countries on numerous types of ethnic favoritist policies such as "scholarships, government jobs, business contracts and army posts" (Groelsema, 1998, p. 417; cf. Young, 1976, among others). The formal theoretical basis for this type of targeting is that Presidents are reliant upon their ethnic brethren - or related ethnic groups (Dickens 2018) - for political support, whom they must reward with higher public spending in order to stay in office (Burgess et al., 2015; Padró i Miquel, 2007). As for why politicians target their ethnic kin rather than other social groups based around linguistic, religious or class identities, the fact that ethnicity is relatively difficult to switch compared to other identities makes it ideal as a way to identify those who will receive benefits from the state (Caselli and Coleman II, 2013; Fearon, 1999).

We should expect ethnic favoritism to be more prominent in non-democracies than in democracies, both because citizens in democracies have greater access to information via the media and can therefore better hold governments to account, and because governments in multi-ethnic democracies without an ethnic majority can only obtain an electoral majority via a cross-ethnic coalition, as compared to a more narrow mono-ethnic basis that is possible in a non-democracy. As such, a majority of the scholarship on the topic presents evidence that ethnic/regional favoritism is either diminished or absent under democratic rule (Ahlerup \& Isaksson, 2015; André et al., 2018; Burgess et al., 2015; Hodler \& Raschky, 
2014). ${ }^{1}$ Another way to put this argument is that democratization diminishes both the supply and demand for ethnic favoritist policies from the government's perspective, such that the former declines due to greater scrutiny of the government from the media and opposition parties, while the latter declines due to a need for governments to reach out to multiple ethnic groups to form a winning coalition. Relatedly, democratization also reduces the potential for reprisals against members of the former President's ethnic group, which have been a common phenomenon in non-democracies such as Liberia (Ellis, 1995) and Uganda (Mazrui, 1980) and which could lead members of such groups to switch identities after their co-ethnic President falls from power.

As regards theories of ethnic change, if one takes a primordial view of ethnicity, such that individuals are stuck with the ethnic group they were assigned at birth, then those who are not co-ethnic with the President must merely suffer until the next regime change possibly provides them with their "turn to eat." However, a more constructivist or instrumentalist understanding of ethnicity would suggest that individuals can and do switch ethnic identities given incentives to do so, as long as the ethnic groups that they shift between are ones in which they could plausibly claim membership. Indeed, there is evidence from Posner (2005) on how shifts in political institutions (specifically the nature of the party system) in Zambia led individuals to shift from language-based identities in a multi-party system to tribal identities in a one-party system and back again. Similarly, Laitin (1998) shows that the break-up of the USSR altered incentives in language choice for both Russian and titular language speakers in a number of post-Soviet states. In a developed country context Nix and Qian (2015) show that better socio-economic opportunities for whites relative to blacks was correlated with greater racial "passing" by African-American men in the late $19^{\text {th }}$ and early $20^{\text {th }}$ century, while Antman and Duncan (2015) similarly show the effect of affirmative

1 The exceptions include Dickens (2018), Franck \& Rainer (2012), and Kramon \& Posner (2016), who find no effect for democracy in diminishing the role of ethnic favoritism. 
action policies on racial identification in the contemporary United States. Finally, Cassan (2015) provides evidence that legislation in colonial India incentivized the individual-level manipulation of caste identity for the purposes of acquiring land. The same logic applies in cross-national analyses as well: Wimmer (2018) suggests that states provide incentives for individuals to identify with the nation when they provide public goods, while Green (2019) shows that individuals give up more parochial tribal identities and adhere to larger ethnic identities during periods of industrialization. Within this literature, Cassan (2015), Laitin (1998) and Nix and Qian (2015)'s work is particularly relevant inasmuch as the identity shifts they document occur along horizontal rather than vertical lines, inasmuch as individuals shift identity from one comparable, exclusive social group to another (rather than from a smaller identity to a larger one). ${ }^{2}$

Of course, as already noted, ethnicity forms the basis for clientelistic politics precisely because it is hard to change, and thus it should be a rare event relative to vertical ethnic change, even given the strong incentives discussed above. Put another way, the costs of such a shift are high: "like learning a second language in adulthood, the process is exhausting and the results usually far from perfect” (Bentley, 1987, p. 35). It is thus not surprising that evidence for racial passing in the late $19^{\text {th }}$ and early $20^{\text {th }}$ century United States suggests that "only" around 19\% of African-American men passed for white at some point during their lifetime, despite the huge incentives to do so (Nix \& Qian, 2015).

In the African context ethnic passing might even be more difficult than racial passing in the US, since individuals who wished to pass might have to learn a new ethnic language.

\footnotetext{
${ }^{2}$ There is, of course, other political incentives driving ethnic identity change that lie outside the focus of this paper, such as cross-national norms that have altered what it means to be "indigenous" in Africa and elsewhere (cf. Igoe, 2006), not to mention the vast literature on how colonial institutions altered ethnic identities in Africa as discussed below. I thank a referee for this point.
} 
Indeed, there is arguably more historical evidence of ethnic passing in Africa for migrant groups (such as the descendants of slaves in West Africa) than for non-migrants (Rossi, 2014, p. 28). During the colonial period examples of passing were rare relative to cases of top-down forced assimilation, whereby tribal chiefs and leaders attempted to incorporate indigenous ethnic minorities against the will of their subjects in their European-delineated, ethnically-homogenous homelands (Doyle, 2009; Mamdani, 1996).3 Even in the postcolonial context passing is not as common as might be expected given the demonstrated difficulties among Africans in correctly identifying their co-citizens' ethnic identities in social contexts, especially in urban settings (Habyarimana et al., 2009; Harris and Findley, 2014).

However, it should be easier to shift one's identity on surveys and censuses than on a day-to-day basis, inasmuch as the former merely requires answering the question of one's ethnic identity differently while the latter might involve passing as a member of a given group by speaking the ethnic language, switching dress, changing one's name, etc. On the one hand this type of switching might not be considered a "real" example of ethnic switching since the individuals in question might fail to adopt the cultural signifiers which are associated with their claimed ethnic identity. Yet, on the other hand, the degree to which any identity shift is "real" or not should arguably rest on an emic, or self-defined, understanding of ethnicity rather than an etic, "objective" imposition of identity by the outsider (Eriksen, 1993, p. 11; Moerman, 1965). Moreover, the consequences of switching on censuses or surveys can have more important implications for the allocation of resources than day-to-day passing, as seen in the aforementioned examples of colonial India, where land was allocated to certain castes on the basis of how individuals identified on census

\footnotetext{
3 See also Gil-White (1999) for a critique of anthropological accounts of passing in Africa and elsewhere.
} 
forms (Cassan, 2015). As such I focus in the rest of this paper on ethnic switching in surveys and leave aside evidence on day-to-day ethnic passing.

Given the above discussion, I can now generate three sets of hypotheses, all of which I test below. The first set involves the relationship between ethnic switching and democracy. Hypothesis \#1.1 is that the incentives for ethnic switching should be higher in nondemocracies than in democracies, due to the fact that ethnic favoritism is more concentrated in non-democracies. As such, the magnitude of this shift should increase the more nondemocratic the context, and the more there is evidence for ethnic favoritism. Hypothesis \#1.2 is that the onset of democratization will generate incentives for people to switch out of the previous ruler's ethnic group but not into the new leader's group, as those who had switched into the previous ruler's ethnic group revert back to their "true" ethnic identities while there are no incentives to switch into the new leader's group due to the demise or decline of ethnic favoritism.

The second set of hypotheses involves the nature of ethnic switching. Hypothesis \#2.1 is that I should expect to find more evidence of ethnic switching than other types of identity switching, particularly as regards religion, since favoritist policies are more likely to allocated along ethnic lines than other types of identity cleavages such as religion. Relatedly, Hypothesis \#2.2 is that ethnic groups that are linguistically similar to the president's ethnic group should also see an increase in their numbers, since they also benefit from ethnic favoritist policies (albeit less so than co-ethnics; Dickens [2018]). Hypothesis \#2.3 is that I should find more evidence of ethnic identity switching than switching in the use of ethnic languages, since the former involves merely changing the answer to a survey question while the latter is difficult and more associated with ethnic passing than switching. More specifically, if individuals were merely strategically switching their ethnic identity on the survey for the purposes of getting a government job or drawing more public resources to their home area, but were not engaged in actual ethnic passing, then we should not observe any relationship between the President's ethnic group and the proportion of the interviewees 
who conducted the interview in the ethnic language of the President. However, we should still be able to observe switching in the coding of the interviewee's native language on the lines that his/her knowledge of that language would not be tested by the interviewer and that one's native ethnic language and ethnic identity are expected to be synonymous.

The third and last set of hypotheses involves when, where and among whom ethnic switching is likely to be found. Hypothesis \# 3.1 is that, if individuals switch in anticipation of receiving government favors, then switching should take place immediately after a presidential transition. However, it is possible that individuals actually switch identities in response to government favors, such that the provision of public goods induces assimilation into the President's ethnic group (Wimmer, 2018). Thus Hypothesis \#3.2 is that switching will not be immediate and will only take place after governments have had time to alter policies of public goods provision. Similarly, Hypothesis \#3.3 is that an increase in access to public goods will lead to ethnic switching, independently of any effect of democratization.

If switching is indeed driven by the desire for government favors, then we can derive two alternative hypotheses about where switching should take place. Hypothesis \#3.4 is that, if individuals are interested in attracting more public goods to their area, then ethnic switching should be greater in more ethnically heterogeneous countries and regions. More specifically, there are few incentives to switch identities in areas with an ethnic majority if one is seeking spending on local infrastructure like roads, hospitals and schools, which will most likely be allocated to areas dominated by the President's ethnic group regardless of the individual identities of those living in such areas (cf. Li, 2018); in contrast, signaling an increase in the proportion of co-ethnics through ethnic switching in a mixed area is more likely to result in greater public goods provision. ${ }^{4}$ However, if individuals are interested in

4 This argument still assumes that 1) enough people in a given locality will decide to switch ethnic identities such that there will be notable shift in local demography, and 2) the shift 
attracting more private goods from the government in the form of employment or contracts, then more diverse areas should not necessarily have higher levels of switching. In fact, if we take into account concerns over retribution once a co-ethnic leader falls from power, then Hypothesis \#3.5 states that we should observe more switching in the home regions of Presidents than elsewhere. Indeed, there is a great deal of evidence that violent reprisals towards the co-ethnics of former leaders target individuals rather than areas (Ellis, 1995; Mazrui, 1980), such that switching identities in the home region of the former President could be very beneficial. 5 Finally, if switching is driven by the desire for private goods such as government employment, Hypothesis \# 3.6 is that unemployed individuals are more likely to switch than those already in employment, since the former group is more likely to seek and benefit from government jobs or favors than the latter group.

Cross-National Data Analysis

There already exists an abundance of anecdotal evidence from Africa of incentivized assimilation into the President's ethnic group. For instance, in Uganda it was well known that President Idi Amin favored his Nubian ethnic group in Uganda in the 1970s in the government, the army and the private sector. Thus, "given the present political and economic advantages in possessing Nubian status ..., it is quite probable that more than half

will come to the government's attention, neither of which are entirely plausible. I thank a referee for this point.

5 See for instance Ellis (1995, p. 167)'s description of the targeting of Krahn in Liberia after Samuel Doe fell from power in 1990: "war-bands moved into Grand Gedeh County, the Krahn heartland, committing atrocities against people guilty of speaking the same mothertongue as Doe," rather than all residents of Grand Gedeh County (roughly 3/4 of whom identify as Krahn). 
of those claiming Nubian identity today grew up with the objective indicators of other ethnic units" (Kasfir, 1979, p. 385). In Kenya President Daniel arap Moi’s regime favored his coethnic Kalenjin in the mass provision of education, infrastructure as well as elite positions in the public and private sector in the 1980s (Burgess et al., 2015; Hornsby, 2012; Kramon \& Posner, 2016; Li, 2018). As such it was not particularly mysterious that the 1989 census showed "the highest growth rates... in communities seen as aligned to the government, membership of which might confer some advantages" (Hornsby, 2012, p. 452), although the census results have been called into question by outside observers.

For a more comprehensive examination of this phenomenon, I now turn towards quantitative evidence. My data mostly come from surveys conducted by the Demographic and Health Survey (DHS) Program (50 surveys) alongside five additional surveys from the UNICEF Multiple Indicator Cluster Survey (MICS) Program and one from the World Fertility Survey (WFS). Both the DHS and MICS surveys have been conducted across lowerand middle-income countries since the late 1980 s, while WFS surveys were conducted in the late 1970 s and early 1980s. (The DHS surveys are essentially updated and expanded versions of the WFS surveys; both sets of surveys are/were run by USAID.) While not explicitly run by country governments, the fact that the DHS and MICS surveys are administered and funded by donors in countries where large amounts of the government are donor-funded could lead many interviewees to think that the survey data would eventually make its way to the government.

The main focus of all three survey programs has been to collect data on fertility, family planning, health and nutrition across a wide range of low- and middle-income countries. As such they focus on women of reproductive age (15-49), although in some cases they have also included men in its surveys (as discussed below). The DHS and MICS surveys are useful for my purposes here as they tend to be conducted around every 4-6 years with a relatively large number of respondents: the lowest number of respondents for a country-survey in my 
sample is the 2009 Liberia survey with 4397 respondents, ${ }^{6}$ while the largest is the 2013 Nigeria survey with 38,948 respondents. The structure of the surveys is always the same across countries and years, such that individuals are asked first about basic personal data (age, education, access to public goods, and asset ownership) before being asked about their religious and ethnic identity.7 Data on ethnicity has been collected for the majority of country-surveys, and thus the DHS/MICS data is particularly useful for the study of ethnic politics in countries like Tanzania where census data on ethnicity has not existed for decades. As such in recent years the DHS data on ethnic identity has been used in a number of papers (Franck \& Rainer, 2012; Kramon \& Posner, 2013; Kramon \& Posner, 2016; Østby, 2008), albeit never as a dependent variable as in this paper.

The DHS and MICS programs have conducted surveys in almost all African countries, but in some cases they have not asked respondents about their ethnic identity across multiple surveys (e.g. Guinea-Bissau and Mozambique) or the data on ethnicity is not comparable across surveys (e.g. Gambia). In other cases there exists multiple rounds of data on ethnic identity but the countries have not experienced any ethnic presidential transitions

\footnotetext{
${ }^{6}$ To put this number in perspective, recall that that the largest Afrobarometer surveys only collect data from 2400 respondents. The Afrobarometer - which is the only other largescale source of cross-national times-series data on ethnic identity in Africa - not only has much smaller surveys and a small number of countries covered than the DHS but has very poor coverage among non-democracies and has much greater within-country variation in the number of ethnic categories, making it impossible to use for my purposes.

7 There is a growing literature on interviewer effects in surveys, particularly in Africa (Adida et al. 2016). In response, the DHS began generating fieldworker datasets from round 7 , which list the interviewers' ethnicity, age and other personal characteristics. Future research that draws upon multiple rounds with fieldworker datasets may be able to assess the degree to which interviewer effects exist for ethnic identity in DHS surveys.
} 
(e.g. Congo-Brazzaville, Cameroon, Gabon and Togo). ${ }^{8}$ I am thus left with fourteen countries with ethnic presidential transitions and consistent data on ethnicity across two or more surveys, which is actually two-thirds of the African countries where there was an ethnic presidential transition between 1986 and 2016;9 within these fourteen countries the data covers a majority (24 out of 41 ) of ethnic presidential transitions (not including Presidents whose term in office was less than one year; for data see Table A.1). Moreover, these countries are broadly representative of Africa as a whole, as can be seen in a series of difference-of-means test comparing countries included in the dataset vs. those not included across a number of relevant variables in Table A.2.10

I use these multiple surveys per country to generate panel data at the level of the country-ethnic group across the multiple rounds of the DHS, as the DHS does not generate individual-level panel data across multiple surveys (unlike Nix and Qian, 2015). In order to use round fixed effects and maintain a roughly comparable number of surveys per country I

8 Not surprisingly, these countries also have mostly seen no change in their level of democracy between surveys, making them irrelevant for my analysis even when using a continuous measure of democracy.

9 I use these dates as it excludes the first (Kenya 1977) and last (Benin 2017) surveys in my dataset.

${ }_{10}$ The only variable that is statistically different at the $5 \%$ level across the two columns is the mean Polity score, such that countries included in the dataset have a mean score of 5.6 vs. 1.3 in non-included countries. This difference is, of course, driven by the fact that I only included countries which have experienced regime change, which biases the sample towards democracies. If I instead include all countries which have had two or more DHS surveys with ethnic data, which adds six additional countries to the original list of fourteen, then the Polity variable is no longer significant at the $5 \%$ level (as seen in the following row in Table A.2). 
used only one survey per round..$^{11}$ In a small number of cases the country surveys do not list the same number of ethnic categories as they do in other rounds; as a rule of thumb I exclude all surveys which do not include ethnic groups that are $1 \%$ or more on average of the country's population in other surveys. (Examples of excluded groups include the Gruma and Grussi in Ghana in 1988 and the Soninke in Senegal in 1986 and 1999.) ${ }^{12}$ I only include data on ethnic groups that are on average $1 \%$ or more of the population, primarily because no ethnic group smaller than $1 \%$ had a co-ethnic become President among the countries in my sample in between the first and last DHS surveys, ${ }^{13}$ but also because a minimum group size of $1 \%$ is the same threshold previously used when computing country-level ELF measures (cf. Fearon, 2003). While some surveys ask a question about which languages respondents use at home, the vast majority (44 out of 56) do not, which does not allow me to address hypothesis \#2.3 using cross-national data (although I am able to do with the Zambian data

${ }^{11}$ I use the comparable DHS round for the five MICS surveys; I coded the one WFS survey as "round zero," which is appropriate given the fact that the WFS surveys functioned as predecessors of the DHS surveys. In cases where there were multiple surveys per round I chose the survey with the largest number of respondents.

12 The main reason I cannot include data from more WFS surveys is that they have different lists of ethnic categories from later DHS and MICS surveys (along with different lists of regional sub-units).

13 The smallest ethnic group to have a co-ethnic President in the dataset was the Lenje of Zambia, with an average of $1.4 \%$ across the DHS surveys and Levy Mwanawasa as its coethnic President (in office 2002-2008; cf. Appendix 1.1 below). Outside the sample there have been a number of African Presidents from even smaller groups, such as Tanzanian President Jakaya Kikwete (in office 2005-2015) from the Kwere group and Nigerian President Ibrahim Babangida (1985-1993) from the Gwere group. 
below). In all cases I use data weighted by the DHS/MICS at the enumeration level to account for uneven sampling and non-responses.

Coding the ethnic group of the President is generally unproblematic, with the possible exceptions of Liberia, Mali and Zambia (as discussed in Appendix 1.1). My sample thus consists of a total of 56 surveys across 14 countries, with descriptive statistics by country listed in Table 1. As can be seen there is variation in the number of surveys per country, from a minimum of two in Tanzania to six in Kenya and Senegal; similar variation exists in the average number of survey respondents per country and the number of ethnic groups per country. There is also notable variation in the number of surveys for which there are male respondents, such that in Liberia there is no time variation. 
Table 1: Countries and Surveys in the Dataset

\begin{tabular}{|c|c|c|c|c|c|c|c|}
\hline Country & Surveys & $\begin{array}{l}\text { Average } \\
\text { Survey Size }\end{array}$ & $\begin{array}{l}\text { Ethnic } \\
\text { Transitions }\end{array}$ & $\begin{array}{l}\text { Total \# of } \\
\text { Ethnic Groups }\end{array}$ & $\begin{array}{l}\text { \# of EGs }>1 \% \\
\text { of population }\end{array}$ & $\begin{array}{l}\text { Average \% of } \\
\text { all EGs }>1 \%\end{array}$ & $\begin{array}{l}\text { Avera } \\
\text { ruling }\end{array}$ \\
\hline Benin & $\begin{array}{l}\text { 1996, 2001, 2006, 2011, } \\
2017\end{array}$ & 12,272 & 1 & 8 & 8 & $12.1 \%$ & $14.4 \%$ \\
\hline CAR & $1994, \mathbf{2 0 0 0}, \underline{2006}, \underline{2010}$ & 11,948 & 1 & 9 & 9 & 10.6 & 18.1 \\
\hline Côte d'Ivoire & $1994,2005,2011$ & 7781 & 2 & 58 & 18 & 4.0 & 10.5 \\
\hline Ghana & $\begin{array}{l}1993,2003,2008, \text { 2011, } \\
2014\end{array}$ & 7027 & 2 & 7 & 7 & 14.0 & 33.2 \\
\hline Guinea & $1999,2005,2012, \underline{\mathbf{2 0 1 6}}$ & 8524 & 1 & 6 & 6 & 16.4 & 25.0 \\
\hline Kenya & $\begin{array}{l}\text { 1977, 1988, 1993, 2003, } \\
\text { 2008, } 2014\end{array}$ & 11,806 & 2 & 10 & 9 & 10.4 & 18.8 \\
\hline Liberia & 1986, 2009, 2013 & 6291 & 1 & 16 & 15 & 6.4 & 4.5 \\
\hline Malawi & $2000,2010,2015$ & 20,267 & 1 & 9 & 9 & 10.9 & 16.4 \\
\hline Mali & $\begin{array}{l}\text { 1995, 2001, 2006, 2012, } \\
\mathbf{2 0 1 5}\end{array}$ & 11,016 & 3 & 9 & 9 & 10.5 & 19.7 \\
\hline Niger & $1992,1998,2006$ & 7749 & 2 & 8 & 5 & 19.5 & 28.9 \\
\hline Nigeria & $2003,2008,2013, \mathbf{2 0 1 5}$ & 21,997 & 3 & 188 & 9 & 8.0 & 6.0 \\
\hline Senegal & $\begin{array}{l}\text { 1992, 1997, 2005, 2006, } \\
\text { 2010, } 2014\end{array}$ & 10,439 & 1 & 6 & 6 & 15.6 & 27.4 \\
\hline Tanzania & 1991,1996 & 8679 & 1 & 123 & 30 & 2.5 & 2.6 \\
\hline Zambia & 1996, 2007, 2013 & 10,793 & 2 & 47 & 17 & 5.2 & 15.0 \\
\hline \multicolumn{2}{|c|}{ Average across all countries } & 10,950 & 1.6 & 36.0 & 11.2 & 9.2 & 18.7 \\
\hline
\end{tabular}

Bold indicates data is available for women only. Underlined data is from UNICEF MICS; italicized data is from the World Fertility Survey. All descriptive statistics is given for females only. 
In Table A.3 I list all 25 ethnic presidential transitions included in the database, with data given on the year of the transition, the subsequent survey, the president who was in office in the previous survey and his/her ethnic group and the subsequent president and ethnic group. In some cases, as indicated in the table, there was more than one president in between the previous and subsequent surveys; in most cases this was only one President but in Liberia seven heads of state came and went in between the 1986 and 2009 surveys.

Finally, I wish to code the level of democracy in each country in accordance with my theoretical predictions detailed above. In order to make the coefficients easier to interpret I invert the annual Polity democracy index, which ranges from -10 (autocracy) to +10 (democracy) to generate an autocracy index which I rescaled from o (full democracy) to 1 (full autocracy). For my main variable of interest I thus interact having a co-ethnic President with the country-year autocracy score for my baseline specification, with alternative data from V-Dem and Freedom House used below in my robustness checks.

Empirical Model and Results

In order to understand the relationship between ethnic identity and presidential regime change I regress the percentage identifying with a given country-ethnic group on a co-ethnic President dummy variable as well as the interaction between the co-ethnic President and Autocracy variables, while controlling for the level of autocracy and countryethnic group and round fixed effects while clustering standard errors at the country-ethnic group level. I also control for the percentage of respondents in each country/survey who are located within a given country-ethnic group's homeland, defined here as the highest-level administrative unit which has the highest average proportion of respondents from a given country-ethnic group. (Thus the homelands for the Luhya of Kenya and the Soussou of Guinea are the Western and Kindia provinces, respectively; see Appendix 1.2 for more 
detail.) By doing so I can control for changes in the regional distribution of respondents, such as in Mali when ongoing conflict meant that neither the 2012 nor 2015 survey was conducted in the Gao, Kidal or Tombouctou regions, leading to a sharp decline in the proportion of respondents identifying as Songhai between 2006 and 2012. The basic model to be estimated is thus

$$
Y_{i c t}=\alpha+\gamma_{i c}+\delta_{t}+\beta \mathrm{CE}_{i c t}+\zeta\left(\mathrm{CE}_{i c t} * \mathrm{~A}_{c t}\right)+\eta H R_{i c t}+\varepsilon_{i t}
$$

where $Y_{\text {ict }}$ is the percentage of the population for country-ethnic group $i$ in country $c$ in round $t$; $\gamma_{i c}$ and $\delta_{t}$ are country-ethnic group and round fixed effects, respectively; $C E_{i c t}$ is the coethnic President dummy; $A_{c t}$ is the measure of autocracy for country $c$ in round $t ; H R_{i c t}$ is the percentage of the survey in the country-ethnic group's home region; and $\varepsilon_{i c t}$ is the error term.

I begin my analysis in column 1 of Table 2 without an interaction term, where the coefficient on having a co-ethnic President is positive but small in magnitude and not statistically significant. In column 2 I include the interaction term, which, at 0.036 , is positive and statistically significant at conventional levels, thereby demonstrating support for Hypothesis \#1.1. Note that the non-interacted co-ethnic President variable is now negative and statistically significant as well, which, when taken together with the interaction term, suggests that the effect of ethnic regime change on the size of president's ethnic group is negative for full democracies (i.e., countries with a Polity score of 6 or above), but turns positive for countries with a Polity score of 5 or below, which interestingly corresponds exactly to the group of countries classified by Polity as anocracies ( 5 to -5 ) and autocracies (-6 to -10$)$. The size of the coefficient is significant as well: for countries with a Polity score of -5 - or borderline autocracies, similar to contemporary African states like Cameroon (-4), Congo-Brazzaville (-4), the Democratic Republic of Congo (-3), Equatorial Guinea (-6) and Eritrea $(-7)$ - the coefficient is equivalent to a $1.8 \%$ increase in the percentage of the 
President's ethnic group. To put this figure in perspective, when compared to the average size of the ruling ethnic group among all countries in the dataset with Polity scores below $\mathrm{O}$ (17.2\%),14 this shift thus suggests that an average of around 10\% of women who identify with the ruling ethnic group in such a country would not have been members of the group prior to regime change.

In column 3 I add country-round fixed effects to control for control for the possibility that surveys may have been conducted differently across rounds in country-specific ways, with no change in the coefficient on the interaction term (and similar results with country specific time-trends). In column 4 I add a dummy variable and interaction term for ethnic groups whose language is closely related to the ethnic language of the President, which takes the value 1 when the two languages share all but one node in their language tree (such as the Peulh and Serer in Senegal, or the Kru and Krahn in Liberia). This model allows me to test for Hypothesis \#2.2 as regards the effects of ethnic favouritism on ethnic groups closely related to the President's group. As expected I find that the interaction effect for related groups is positive, statistically significant and roughly the same size as the interaction term for co-ethnics, which corresponds with Dickens (2018)'s findings on the positive benefits of ethnic favouritism for related groups. ${ }^{15}$

14 This number does not change if I include country-surveys from countries without ethnic presidential transitions.

15 This finding also suggests that those who are shifting into the President's ethnic group are not switching from related groups, which, if true, would generate a negative coefficient for the related group interaction term rather than the positive coefficient reported in column 4 . It is, however, possible that the positive coefficient is generated by more members of nonrelated groups switching into related groups than members of related groups are switching into the President's group, which is not something I can test with the data. 
In column 5 I recreate the fixed effects model within a three-tiered multilevel model by capturing both time-variant and time-invariant effects (Bell and Jones, 2015); I also explored what time-invariant country-level variables could explain ethnic group size and found only one, namely a Francophone dummy. The size of the coefficient on the interaction term actually increases as compared to previous columns and the Francophone dummy indicates that the average ethnic group in former French colonies in Africa is $3.3 \%$ larger than in other countries, which is itself a novel finding. ${ }^{16}$ In column 6 I control for the possibility that long-term demographic trends might be driving changes in the size of ethnic groups by including a lagged dependent variable and using OLS with standard errors clustered at the country-ethnic group level (Angrist and Pischke, 2009); despite losing over $1 / 4$ of my observations the interaction coefficient remains statistically significant at the $6 \%$ level although it drops in magnitude. Finally, in column 7 I check for reverse causality by coding the co-ethnic President variable (and interaction term) with a lead of five years, to account for the possibility that there is a correlation between the future election of a president and the increase in the size of an ethnic group; as expected neither the co-ethnic President nor the interaction term is statistically significant.

${ }^{16}$ This finding is not surprising, given the abundant evidence for the fact that British (and Belgian) colonialism was more marked by a decentralized divide-and-rule strategy that encouraged ethnic fractionalization than French colonialism (Blanton et al., 2001; Young, 1994). Indeed, as seen in Table 1 , the two countries with by far the largest number of ethnic groups are Nigeria and Tanzania, both former British colonies, while the two countries with the lowest number of ethnic groups, namely Guinea and Senegal, are both former French colonies. 
Table 2: Basic Results

(Dependent Variable: Weighted Percentage of Surveyed Population)

\begin{tabular}{|c|c|c|c|c|c|c|c|}
\hline Model & $\mathrm{FE}$ & $\mathrm{FE}$ & $\mathrm{FE}$ & $\mathrm{FE}$ & MLM & OLS & $\mathrm{FE}$ \\
\hline \multirow[t]{2}{*}{ Sample } & All & All & All & All & All & All & $\begin{array}{l}\text { 5-year } \\
\text { Lead }\end{array}$ \\
\hline & (1) & (2) & (3) & (4) & （5） & (6) & (7) \\
\hline Co-Ethnic President & $\begin{array}{l}0.003 \\
(0.003)\end{array}$ & $\begin{array}{l}-0.009^{* *} \\
(0.004)\end{array}$ & $\begin{array}{l}-0.009^{* *} \\
(0.004)\end{array}$ & $\begin{array}{l}-0.011^{* *} \\
(0.004)\end{array}$ & $\begin{array}{l}-0.015^{* * *} \\
(0.006)\end{array}$ & $\begin{array}{l}-0.007 \\
(0.007)\end{array}$ & $\begin{array}{l}0.005 \\
(0.005)\end{array}$ \\
\hline $\begin{array}{l}\text { Co-Ethnic President * } \\
\text { Autocracy }\end{array}$ & & $\begin{array}{l}0.036^{* * *} \\
(0.009)\end{array}$ & $\begin{array}{l}0.036^{* * * *} \\
(0.009)\end{array}$ & $\begin{array}{l}0.040^{* * *} \\
(0.009)\end{array}$ & $\begin{array}{l}0.05^{* * * *} \\
(0.015)\end{array}$ & $\begin{array}{l}0.044^{* * * *} \\
(0.015)\end{array}$ & $\begin{array}{l}-0.003 \\
(0.010)\end{array}$ \\
\hline Autocracy Score & & $\begin{array}{l}-0.006 \\
(0.006)\end{array}$ & $\begin{array}{l}-0.040 \\
(0.046)\end{array}$ & $\begin{array}{l}-0.007 \\
(0.006)\end{array}$ & $\begin{array}{l}-0.004 \\
(0.004)\end{array}$ & $\begin{array}{l}-0.006 \\
(0.005)\end{array}$ & \\
\hline $\begin{array}{l}\text { Percentage in Ethnic Group's } \\
\text { Home region }\end{array}$ & $\begin{array}{l}0.295^{* * *} \\
(0.043)\end{array}$ & $\begin{array}{l}0.282^{* * *} \\
(0.042)\end{array}$ & $\begin{array}{l}0.297^{* * *} \\
(0.056)\end{array}$ & $\begin{array}{l}0.280^{* * *} \\
(0.042)\end{array}$ & $\begin{array}{l}0.272^{* * *} \\
(0.031)\end{array}$ & $\begin{array}{l}0.037^{* *} \\
(0.016)\end{array}$ & $\begin{array}{l}0.287^{* * *} \\
(0.041)\end{array}$ \\
\hline $\begin{array}{l}\text { President from Related Ethnic } \\
\text { Group }\end{array}$ & & & & $\begin{array}{l}-0.026^{* *} \\
(0.010)\end{array}$ & & & \\
\hline $\begin{array}{l}\text { Related Group President * } \\
\text { Autocracy }\end{array}$ & & & & $\begin{array}{l}0.051^{* *} \\
(0.022)\end{array}$ & & & \\
\hline Francophone dummy & & & & & $\begin{array}{l}0.033^{*} \\
(0.017)\end{array}$ & & \\
\hline Percentage (lagged) & & & & & & $\begin{array}{l}0.963^{* * *} \\
(0.012)\end{array}$ & \\
\hline Constant & $\begin{array}{l}0.055^{* * *} \\
(0.009)\end{array}$ & $\begin{array}{l}0.060^{* * * *} \\
(0.010)\end{array}$ & $\begin{array}{l}0.090^{*} \\
(0.050)\end{array}$ & $\begin{array}{l}0.061^{* * * *} \\
(0.010)\end{array}$ & $\begin{array}{l}0.039^{* * *} \\
(0.015)\end{array}$ & $\begin{array}{l}0.0006 \\
(0.002)\end{array}$ & $\begin{array}{l}0.057^{* * *} \\
(0.012)\end{array}$ \\
\hline Country-Ethnicity Fixed Effects & yes & yes & yes & yes & & & yes \\
\hline Round Fixed Effects & yes & yes & yes & yes & & & yes \\
\hline Country-Round Fixed Effects & no & no & yes & no & & & no \\
\hline Countries & 14 & 14 & 14 & 14 & 14 & 14 & 14 \\
\hline Surveys & 56 & 56 & 56 & 54 & 56 & 42 & 51 \\
\hline
\end{tabular}


Country-Ethnic Groups

Observations

157
558

157

558

${ }^{*} \mathrm{p} \leq 0.1,{ }^{* *} \mathrm{p} \leq 0.05,{ }^{* * *} \mathrm{p} \leq 0.01$. The table reports robust standard errors clustered at the country-ethnic group level. 


\section{Robustness Tests}

In Table A.4 I test for the robustness of my results as well as some of the other hypotheses generated above. In column 1 I include the additional 14 DHS/MICS surveys that I previously neglected inasmuch as they were conducted in the same round as other, larger surveys, with no real change in my results. Column 2 only includes surveys conducted on either side of an ethnic presidential change to test Hypotheses \#3.1 and \#3.2 on when ethnic switching occurs; the fact that the coefficient actually increases in size in this specification suggests that switching is immediate and thus confirms Hypothesis \#3.1. Column 3 tests Hypothesis \#2.1 on whether the religious identity of the president has any effect on religious identification among survey respondents, with the evidence supporting the hypothesis. Column 4 includes data from men only; despite a smaller sample size the reported coefficient is larger than the female-only sample. In column 5 I combine the data for all men and women aged 15-49, which means losing more than 1/4 of my observations; nonetheless, the coefficient remains steady and statistically significant.

I also conducted a number of alternative robustness tests. Dropping one country at a time from my analysis yields no notable changes in the coefficient on the interaction term. I then examined one country at a time without an interaction term; as seen in Table A.5, the coefficient on the co-ethnicity variable is positive and statistically significant at the $10 \%$ level for five out of seven countries with an average Polity score below 4.0 despite very low samples sizes (and is only slightly imprecisely estimated for Guinea and Niger). In contrast, of the seven countries with average Polity scores above 4.o, three have negative coefficients, of which two (Benin and Zambia) are actually statistically significant.

In Table A.6 I considered alternative measures of democracy, namely the continuous measures of democracy from Freedom House, the Press Freedom Index (only available from 1992 onwards) and V-Dem's Polyarchy Index. In all three cases the results correspond with 
my previous findings and confirm Hypothesis \#1.1. These measures of democracy are, however, effectively proxies for the degree to which countries are prone to ethnic favoritism. As such I replicate Ahlerup and Isakkson (2015)'s findings to generate separate countryaverage coefficients from their analysis of the effect of having a co-ethnic President on whether members of a given ethnic group feel that they are treated unfairly by the government, such that the lower the coefficient, the greater the effect of a co-ethnic president. As expected, the coefficient on the interaction of this measure and a co-ethnic president in column 4 of Table A.6 is negative and statistically significant; similarly, when comparing the country-average coefficients with my country-average coefficients from Table A. 5 in Figure A1, there is a clear negative correlation. ${ }^{17}$ In other words, ethnic switching is more prevalent in countries where citizens perceive more ethnic favoritism, which is consistent with my theoretical expectations. (I find similar findings when using Hodler and Raschky [2015]'s data on the effect of co-regional presidents on night-time light intensity, as seen in Figure A2.)

In Table A.7 I checked if my results could be an artefact of either oversampling or a higher overall response rate among women in the President's home region or the home region of the President's ethnic group, which could be a result of the fact that co-ethnics might be more likely to agree to take the survey if they think it is sponsored by the government; however, I find no evidence in support of either thesis. Finally, as reported in Table A.8 I controlled for a variety of other variables that could affect the relationship between ethnic presidential change and ethnic change. In column 1 I added an variable controlling for having a co-ethnic attain power in a neighboring country, which plausibly

${ }_{17}$ I do not use coefficients from Franck and Rainer (2012) here for two reasons: 1) the period they cover extends back to the 1960 s and ends in the mid-200os and is thus very different from the period my data covers, and 2) they are missing data from Côte d'Ivoire, Tanzania and Zambia. 
could lead members of the same ethnic group in the original country to emigrate to the neighboring country in order to receive the benefits of ethnic favoritism (such as happened under Idi Amin in Uganda in the 1970s). Here the coefficient is positive and statistically significant, which is the opposite of what one would expect if people were migrating to neighboring countries with a co-ethnic President in power. In columns 2-4 I add additional interactions for country-year values of GDP per capita, total years of primary and secondary schooling, and state antiquity values, inasmuch as all three variables were shown to be correlated with regional favoritism at a global level in previous scholarship (De Luca et al., 2018; Hodler \& Raschky, 2014). In column 5 I added an interaction for Fearon (2003)'s country-level (time-invariant) ELF in order to test Hypothesis \#3.4, namely that more diverse countries should see greater amounts of ethnic switching. Similarly, in column 6 I control for an interaction with Desmet et al. (2012)'s alternative country-level (timeinvariant) measure of "deep" ethno-linguistic cleavages, which may affect the ability of individuals to switch ethnic identity to a group very different culturally from their own. In column 7 I used data calculated from DHS Couples datasets on the average rate of interethnic marriage by country-survey; I then interacted the intermarriage measure and the coethnic President variable to assess whether a higher incidence of intermarriage leads to more ethnic switching. Finally, in columns 8 and 9 I tested for evidence of hypothesis \#3.3 on an independent effect of public goods provision on ethnic identity; to do so I used the two measures of public goods included in DHS surveys, namely access to electricity and piped water supplies. In none of these cases is the additional control statistically significant at conventional levels while the main effect remains largely untouched.18

18 I tried other interaction effects which were correlated with ethnic favoritism in the literature and which would provide additional tests of hypothesis \#3.3, such as average taxation as a percentage of GDP, average revenue as a percentage of GDP, average 
Within-Survey Evidence from Zambia

While the previous section shows that the cross-national results are robust in a variety of ways, there are still potential problems from using repeated samples measuring the same outcome from different surveys. One issue is that the surveys used in the study are almost identical in design but do contain some differences which could affect ethnic identification, such as the number of ethnic categories listed in the questionnaire (which might affect the identification of those from mixed-ethnic backgrounds). The surveys also differ in their timing in relation to political transitions and other broader structural changes in society (such as immigration and intermarriage), all of which have the potential to affect ethnic identification.

Examining the effect of a transition on ethnic identification during a single survey conducted across a period of transition would thus help to alleviate these concerns, while also testing with more rigor Hypotheses \# 3.1 and \#3.2 about the timing of ethnic switching. In three cases the DHS has conducted such a survey, with the possibility of observing withinsurvey evidence on ethnic switching before and after the transition. Two of the three surveys are from Malawi, namely from 2012 (from Bingu wa Mutharika [Lomwe] to Joyce Banda [Yao]) and from 2014 (from Joyce Banda [Yao] to Peter Mutharika [Lomwe]); however, in both cases Malawi was arguably already a relatively well-established democracy and thus we would not expect to observe any evidence of ethnic switching (as I do not, with results available from the author upon request).

The third survey, however, is from Zambia in 2001-2002 and covers the transition from Frederick Chiluba (Bemba) to Levy Mwanawasa (Lenje/Tonga). This transition was

government expenditure on education as a percentage of GDP and having a dominant religion (Franck and Rainer, 2012), all of which yielded the same results as in Table A.8. 
marked by a shift in Zambia's Polity score from 1 in 2000 to 5 in 2001, based not only on the change in leadership styles but also the fact that Chiluba obeyed the country's constitutional term limits and resigned in favor of Mwanawasa despite his earlier attempts to extend his reign into a third term. Chiluba was well known both for high levels of corruption and for over-representing his fellow Bemba in his cabinet (Osei-Hwedie, 1998, p. 235); ${ }^{19}$ in contrast, however, during the campaign Mwanawasa assembled a much more multi-ethnic coalition that focussed on picking up rural voters across the country, as well as a cleaner administration (Cheeseman and Hinfelaar, 2010). As such the Zambia case has the potential to test Hypothesis \#1.2 about the effects of regime change on ethnic identities during a period of democratization.

The DHS survey in Zambia took place between early November 2001 and early June 2002 and covered 9803 men and women. The election took place on December 27, 2001, with Mwanawasa defeating the opposition leader Anderson Mazoka by a close tally of 29.2\% to 27.2\%; Mwanawasa then took office on January 2, 2002. It is thus possible to use data only from those people surveyed two months either side of the transition, which yields 2076 observations before the election and 3509 afterwards (with no one surveyed in between the election and inauguration day).20 All of Zambia's (then) nine provinces were sampled both before and after the election within two months of the transition.

To test the effects of the transition on ethnic identity, I use a logit model to regress ethnic identification on whether an individual was surveyed after the election, alongside a variety of co-variates such as age, gender, rural residence, level of education and selfidentification as a Catholic, while clustering the standard errors at the enumeration area; I

19 Much of Chiluba's supposed bias towards the Bemba was more perceived than real (Lindemann, 2011), which, of course, does not make it any less salient politically.

${ }^{20}$ The results are robust to only considering people surveyed one month either side of the transition; they are also robust to male and female-only sub samples. 
also add a dummy for the home region of each group (which is always positive and statistically significant). I start in Table 3 with Bemba ethnic identity as the dependent variable in column 1, and find that, as expected, the coefficient on being surveyed after the election is negative and statistically significant. In columns 2 and 3 I can test Hypothesis \#2.3 that ethnic switching should be apparent in answers to a question about home language but not the interview language, with the results supporting the hypothesis. As expected, column 4 shows that there is no evidence of switching into Mwanawasa's Lenje or Tonga ethnic identities. Column 5 examines evidence for individuals from Kenneth Kaunda's Nyanja ethnic group who may have switched out of their ethnic identity upon Chiluba's accession to power in 1991, and find that the coefficient is positive and statistically significant, suggesting that Mwanawasa's accession led those who had switched their identity in the 1990s from Nyanja to Bemba to switch back again. Columns 6-7 test if there is switching into Nyanja home and interview languages, and find no evidence for either group; one explanation for the lack of a positive relationship in column 6 could be the result of the relatively small number of people who claim Nyanja as their home language (at only $1 / 3$ that of Bemba) as well as the relatively small size of the sample. 
Table 3: Ethnic Identification in Zambia, 2001-2002

\begin{tabular}{|c|c|c|c|c|c|c|c|}
\hline $\begin{array}{l}\text { Dependent Variable: } \\
\text { Language }\end{array}$ & $\begin{array}{l}\text { Bemba } \\
\text { Ethnicity } \\
\text { Language }\end{array}$ & $\begin{array}{l}\text { Bemba } \\
\text { Home }\end{array}$ & $\begin{array}{l}\text { Bemba } \\
\text { Interview }\end{array}$ & $\begin{array}{l}\text { Lenje/Tonga } \\
\text { Ethnicity } \\
\text { Language }\end{array}$ & $\begin{array}{l}\text { Nyanja } \\
\text { Ethnicity } \\
\text { Language }\end{array}$ & Nyanja & Nyanja \\
\hline & (1) & (2) & (3) & (4) & (5) & (6) & (7) \\
\hline Post-Election & $\begin{array}{l}-0.944^{* * *} \\
(0.227)\end{array}$ & $\begin{array}{l}-1.124^{* * *} \\
(0.227)\end{array}$ & $\begin{array}{l}-0.389 \\
(0.301)\end{array}$ & $\begin{array}{l}-0.069 \\
(0.383)\end{array}$ & $\begin{array}{l}0.564^{* *} \\
(0.227)\end{array}$ & $\begin{array}{l}-0.028 \\
(0.291)\end{array}$ & $\begin{array}{l}-0.230 \\
(0.348)\end{array}$ \\
\hline Pseudeo R2 & 0.227 & 0.233 & 0.263 & 0.249 & 0.178 & 0.420 & 0.313 \\
\hline Observations & 5585 & 5585 & 5585 & 5585 & 5585 & 5585 & 5585 \\
\hline
\end{tabular}

${ }^{*} \mathrm{p} \leq 0.1,{ }^{* *} \mathrm{p} \leq 0.05,{ }^{* * *} \mathrm{p} \leq 0.01$. Additional controls include age, age squared, gender, rural residence, level of education, Catholic identification, employment status and a dummy for the home province of each group (Northern province for columns 1-3, Southern Province for column 4, and Eastern Province for columns 5-7); using regional fixed effects instead leads to dropping large numbers of observations for regional dummies which predict failure perfectly. The table reports robust standard errors clustered at the enumeration area. 
If it is true that individuals dropped their Bemba identities after the election and returned to their previous identities as Nyanja, then we should see these parallel shifts taking place in the same areas. In Table A.9 I split the sample into two, first for only the contiguous Eastern, Central and Northern Provinces - which are the home provinces for the Nyanja, Lenje and Bemba, respectively - in Panel A, and then for the rest of the country in Panel B. As is evident, both switching out of Bemba and switching into Nyanja ethnic and language identities is being driven by the three aforementioned provinces (despite containing only a minority of the sample), which provides additional support that these two shifts are taking place among the same people. The fact that this switching is taking place in the Presidents' home regions lends support to Hypothesis \#3.5, which I test more broadly in the next section. ${ }^{21}$

Individual Correlates of Ethnic Switching

The data used in the main analysis above is panel data according to ethnic group but not according to individuals, which means that I cannot get exact information on which types of respondents are engaging in ethnic switching. It is, however, possible to obtain ethnic group data according to sub-samples of each survey, with the caveat that doing so introduces a great deal of noise due to smaller sample sizes, as doing so will help me to test Hypotheses \#3.5 and \#3.6 about where and among whom ethnic switching takes place. I list the results of four sub-samples in Table 4. In columns 1-2 I test Hypothesis \#3.5 that ethnic switching should be concentrated in the home regions of Presidents. Despite the fact that the combined population of these regions comprises only $26 \%$ of the total surveyed

\footnotetext{
${ }^{21}$ As with the cross-country evidence, there is no evidence in Zambia for Hypothesis \#3.4, namely that switching is taking place in provinces with higher levels of ethnic fractionalization; results are available from the author.
} 
population across all surveys, the results very clearly support Hypothesis \#3.5, such that the coefficient for the Presidents' home regions is much larger than outside these regions (0.149 vs. -0.006). In Niger, for example, the proportion of Djerma in their home region of Tillaberi was $71.1 \%$ of the survey in 1992 when their co-ethnic Ali Saibou held the Presidency, while in 1998 and 2006 the proportion of Djerma in Tillaberi dropped to 64.5\% and 59.8\%, respectively, after Saibou fell from power.

Finally, I split the samples into women not in employment and those in employment in columns 3-4 in order to test Hypothesis \#3.6: despite the fact that only $39 \%$ of women are out of employment across the whole sample, the coefficient for unemployed women (o.061) is statistically significant and three times the size of that of employed women (0.020), which is not statistically significant. ${ }^{22}$ These very different results for unemployed and employed respondents are consistent with the theory that respondents are more likely to re-identify ethnically if they are currently jobless and see a shared ethnic identity with the president as something that could help them obtain a job. However, this theory remains speculative and needs further testing with more detailed data.

${ }^{22}$ Additional results when splitting the data into those with below-average and aboveaverage ages and levels of wealth and education, as well as rural vs. urban respondents and illiterate and literate respondents, generated similarly sized coefficients in all cases. 
Table 4: Survey Sub-Samples

(Dependent Variable: Weighted Percentage of Surveyed Population)

\begin{tabular}{|c|c|c|c|c|}
\hline \multirow[t]{2}{*}{ Sub-Sample } & $\begin{array}{l}\text { Presidents' } \\
\text { Home } \\
\text { Region only }\end{array}$ & $\begin{array}{l}\text { Outside } \\
\text { Pres. Home } \\
\text { Region only }\end{array}$ & Unemployed & Employe \\
\hline & (1) & (2) & (3) & (4) \\
\hline $\begin{array}{l}\text { Co-Ethnic President * } \\
\text { Autocracy }\end{array}$ & $\begin{array}{l}0.149^{* * *} \\
(0.037)\end{array}$ & $\begin{array}{l}-0.006 \\
(0.019)\end{array}$ & $\begin{array}{l}0.061^{* * *} \\
(0.020)\end{array}$ & $\begin{array}{l}0.020 \\
(0.019)\end{array}$ \\
\hline Countries & 13 & 13 & 13 & 13 \\
\hline Surveys & 56 & 56 & 44 & 44 \\
\hline Ethnic Groups & 157 & 157 & 148 & 148 \\
\hline Observations & 558 & 558 & 452 & 452 \\
\hline
\end{tabular}

${ }^{*} \mathrm{p} \leq 0.1,{ }^{* *} \mathrm{p} \leq 0.05,{ }^{* * *} \mathrm{p} \leq 0.01$. All regressions include the same controls as in Table 3 . Employment data is missing from the Central African Republic (all surveys), Ghana (2011), Guinea (2016), Kenya (1988), Liberia (2009), Mali (2015), Nigeria (2015) and Senegal (2006). The table reports robust standard errors clustered at the country-ethnic group level. Due to very low sample sizes when splitting the survey I was unable to test these relationships using the Zambian 2001 survey. 
Discussion and External Validity

One final question about my analysis above is the degree to which it applies specifically to non-democracies in post-colonial Africa or more widely. My results suggest that political incentives drive identity change, specifically the degree to which presidents redistribute jobs and resources towards their co-ethnic kin in autocracies and target coethnics of previous leaders for retribution. If these results are generalizable to longer periods of time and beyond Africa (inasmuch as historically the entire world was governed under non-democratic means), then much of the modern variation in ethnic fractionalization could be in part derived from the ability of centralized states to incentivize ethnic assimilation - or at the very least ethnic switching on surveys and censuses - as a means for citizens to acquire access to state resources.

As such, a brief overview of a non-African case study provides further support that the existence of ethnic favoritism can drive identity change in autocracies more broadly. The example comes from early modern China, where the Qing dynasty, dominated by the Manchu ethnic minority, succeeded the Han-majority Ming dynasty in 1644 and ruled until 1912. Qing dynasty emperors provided preferential treatment to Manchus throughout this period, including the ability to achieve higher ranks within the government and receive reduced punishments compared to the Han majority (Wakeman, 1985, p. 873). Indeed, the vast majority of people hired in the civil bureaucracy (especially below the highest level of administration) were Manchu, despite the fact that they only comprised some $1 \%$ of the population (Rhoads, 2000, pp. 45-46). As a result many Han Chinese clearly tried to "pass” as Manchu in order to access state privileges, largely by joining as "bannermen" under the "Eight Banners" system of Manchu military and social classification and assimilating into Manchu society by adopting Manchu-style names and Manchu dress (Elliott, 2001; Rhoads, 
2000, pp. 55, 61).23 Indeed, the increasing number of Han "false Manchus" in the banner system led to reforms in the 1720 s that excluded Han Chinese by using written genealogies to distinguish the two groups (Elliott, 2001, pp. 323-326). This system of preferential treatment came to end when both the dynasty and the Manchu elite fell from power in 1912, whereupon Manchus were targeted for retributive discrimination. With their social status now reversed, many Manchus subsequently changed their names to better assimilate as Han Chinese, while also altering their dress and surnames, adopting local dialects and intermarrying with non-Manchus (Rhoads, 2000, pp. 268-270). Thus the Chinese example shows both how ethnic favoritist policies can generate ethnic switching and how a change in the ethnic identity of the state elite can generate subsequent switching among the formerly dominant elite in a non-African context.

Conclusion

In this paper I used demographic and health survey data from fourteen African countries to show that ethnic presidential transitions lead individuals to switch their ethnic identity towards that of the President in non-democratic contexts. The results indicate that the magnitude of ethnic switching increases with the level of autocracy, such that there is no or even negative ethnic switching in full democracies but high levels in autocracies, such that, in the latter case, a significant proportion of the members of the ruling group would

23 Note that this passing did not necessarily involve changing one's language, since Mandarin Chinese remained the lingua franca throughout the period; as such passing as a Manchu was relatively easy compared to other contexts where one has to learn a new language. Coupled with the lack of censuses or surveys whereby Han Chinese could re-identify as Manchu for official purposes, passing in Manchu Qing dynasty thus looks very similar to ethnic switching in contemporary Africa. 
have previously identified with another ethnic group. Within-survey data from Zambia showed that ethnic switching can be immediate, which provides support for the hypothesis that individuals switch in anticipation of receiving government favors and not in response. Sub-samples from the main dataset showed that the effect was concentrated in the Presidents' home regions and among unemployed women, which is consistent with the desire to avoid retribution and obtain government employment, respectively. Finally, I examined evidence of ethnic favoritism and switching in early modern China, which suggested that the phenomenon of politically-incentivized ethnic switching is not limited to contemporary Africa.

I conclude in two ways, first by speculating on the possibilities for future ethnic change in Africa, and secondly through suggestions for further research. As regards the former, it is important to recall that my results suggest that the incentives for assimilation into the ruling ethnic group operate only in non-democracies. The decline in ethnic favoritism in democracies could explain why ethnic assimilation is so difficult to incentivize in contemporary contexts. There is abundant evidence that recent democratization in Africa and elsewhere has brought about the rise of clientelistic identity-based political parties for minority ethnic groups (Keefer, 2007; Van de Walle, 2003), thereby discouraging assimilation into President's ethnicity inasmuch as these new parties advocate the redistribution of resources to their core ethnic constituencies. In countries without an ethnic majority parties which wish to achieve power must either broaden their appeal beyond their core ethnic constituents or form multi-ethnic coalitions. In countries with ethnic majorities this incentive is not present at the central government level, but democratization still presents political space for minority-based political parties to emerge and disincentivize assimilation. Thus continued and sustained democratization in Africa and elsewhere should lead to lower levels of ethnic switching in the future.

Another future trend that could affect ethnic change is unemployment. More specifically, if structural transformation continues to shift workers from the rural 
agricultural sector to the urban industrial and service economies, while automatization leads to a decline in the number of available jobs, African countries could see a rise in unemployment figures, as has already been occurring in southern African countries like Botswana and South Africa for decades. If, as noted above, ethnic change is more concentrated among the unemployed, then this trend may lead to higher levels of ethnic change in the future. To take one notable example, despite South Africa's high level of democracy it still suffers from accusations of ethnically unbalanced provision of top jobs in government and the ethnic favoritist provision of public services, as per accusations of a "Xhosa Nostra" under President Thabo Mbeki in the former case and statistical evidence on the biased allocation of electricity and water infrastructure in the latter (Walters et al., 2019). It is possible that ethnic favoritism in South Africa has led to ethnic change among its large number of unemployed citizens, and that similar processes could happen elsewhere in Africa in the future.

As regards further research on the topic, there are at least three areas that would benefit closer scrutiny in the future. First, as suggested above, the use of longitudinal survey data would help to identify individual correlates of ethnic switching, along the lines used by Nix and Qian (2015) in their analysis of racial switching in the United States. Such an analysis could, for instance, help to alleviate any concerns about the ecological fallacy of generating country-ethnic group panel data by sampling different groups of people across multiple surveys.

Second, the paper largely focusses on ethnic change among women, inasmuch as the data for men is poorer and sparser. I cannot, therefore, examine whether there are gendered differences in the nature of ethnic switching, which is an important but neglected topic in the literature on ethnicity and nationalism. Future research could thus draw upon surveys with more gender-balanced samples in order to investigate this topic in more detail.

Third and finally, with more data it may be possible in the future to examine the effects of ethnic presidential identity on ethnic change in the long run. Efforts to compile 
panel data on ethnic identity in African countries with and without ethnic presidential transitions are currently stymied by the low number of country-surveys in the latter category with consistent ethnic categories and data on home regions. ${ }^{24}$ Eventually it may be possible to say more about whether the length of tenure in office has an independent effect on ethnic change, which is an important question given the extant literature on how regimes alter their degree of ethnic inclusion over time (Arriola, 2009).

24 The DHS yields only six such countries, namely Burkina Faso, Cameroon, CongoBrazzaville, Gabon, Togo and Uganda, of which only Burkina Faso and Togo have more than two surveys per country. 
Bibliography

Adida, C., Ferree, K. E., Posner, D. N., \& Robinson, A. L. (2016). Who's Asking? Interviewer Coethnicity Effects in African Survey Data. Comparative Political Studies, 49, 16301660.

Ahlerup, P., \& Isaksson, A.-S. (2015). Ethno-Regional Favoritism in Sub-Saharan Africa. Kyklos, 68, 143-52.

André, P., Maarek, P. \& Tapo, F. (2018). Ethnic Favoritism: Winner Takes All or Power Sharing? Evidence from school constructions in Benin. Manuscript. Université de Cergy-Pontoise. https://ideas.repec.org/p/ema/worpap/2018-03.html.

Angrist, J. D., and Pischke, J.-S. (2009). Mostly Harmless Econometrics: An Empiricist's Companion. Princeton, NJ: Princeton University Press.

Antman, F., \& Duncan, B. (2015). Incentives to Identify: Racial Identity in the Age of Affirmative Action. Review of Economics and Statistics, 97, 710-713.

Arriola, L. (2009). Patronage and Political Stability in Africa. Comparative Political Studies, 42, 1339-1362.

Baldwin, K., \& Huber, J. D. (2010). Economic versus Cultural Differences: Forms of Ethnic Diversity and Public Goods Provision. American Political Science Review, 104, 64462.

Bell, A., \& Jones, K. (2015). Explaining Fixed Effects: Random Effects Modeling of TimeSeries Cross-Sectional and Panel Data. Political Science Research and Methods, 3, $133-53$.

Bentley, G. C. (1987). Ethnicity and Practice. Comparative Studies in Society and History, 29, 24-55.

Blanton, R., Mason, T. D., \& Athow, B. (2001). Colonial Style and Post-Colonial Ethnic Conflict in Africa. Journal of Peace Research, 38, 473-92. 
Burgess, R., Jedwab, R., Miguel, E., Morjaria, A., \& Padró i Miquel, G. (2015). The Value of Democracy: Evidence from Road Building in Kenya. American Economic Review, $105,1817-51$.

Caselli, F., \& Coleman II, W. J. (2013). On the Theory of Ethnic Conflict. Journal of the European Economic Association, 11, 161-92.

Cassan, G. (2015). Identity Based Policies and Identity Manipulation: Evidence from Colonial Punjab. American Economic Journal: Economic Policy, 7, 103-31.

Cheeseman, N., \& Hinfelaar, M. (2010). Parties, Platforms, and Political Mobilization: The Zambian Presidential Election of 2008. African Affairs, 109, 51-76.

De Luca, G., Hodler, R., Raschky, P. A., \& Valsecchi, M. (2018). Ethnic Favoritism: An Axiom of Politics? Journal of Development Economics, 132: 115-29.

Desmet, K., Ortuño-Ortín, I., \& Wacziarg, R. (2012). The Political Economy of Linguistic Cleavages. Journal of Development Economics, 97, 322-338.

Dickens, A. (2018). Ethnolinguistic Favoritism in African Politics. American Economic Journal: Applied Economics, 10, 370-402.

Doyle, S. (2009). Immigrants and Indigenes: The Lost Counties Dispute and the Evolution of Ethnic Identity in Colonial Buganda. Journal of Eastern African Studies, 3, 284302.

Elliott, M. C. (2001). The Manchu Way: The Eight Banners and Ethnic Identity in Late Imperial China. Stanford, CA: Stanford University Press.

Ellis, S. (1995). Liberia 1989-1994: A Study of Ethnic and Spiritual Violence. African Affairs, $94,165-97$.

Eriksen, T. H. (1993). Ethnicity and Nationalism: Anthropological Perspectives. London: Pluto.

Fearon, J. D. (1999). Why Ethnic Politics and "Pork" Tend to Go Together. Department of Political Science, Stanford University. 
Fearon, J. D. (2003). "Ethnic and Cultural Diversity by Country." Journal of Economic Growth, 8, 195-222.

Franck, R., \& Rainer, I. (2012). Does the Leader's Ethnicity Matter? Ethnic Favoritism, Education and Health in Sub-Saharan Africa. American Political Science Review, 106, 294-325.

Francois, P., Rainer, I., \& Trebbi, F. (2015). How is Power Shared in Africa? Econometrica, $83,465-503$.

Gellner, E. (2006 [1983]). Nations and Nationalism. Oxford: Blackwell.

Gil-White, F. J. (1999). How Thick is Blood? The Plot Thickens . . .: If Ethnic Actors are Primordialists, What Remains of the Circumstantialist / Primordialist Controversy? Ethnic and Racial Studies, 22, 789-820.

Green, E. D. (2019). Industrialization and Ethnic Change in the Modern World. Ethnic and Racial Studies, 42, 178-197.

Groelsema, R. J. (1998). The Dialectics of Citizenship and Ethnicity in Guinea. Africa Today, 45, 411-21.

Habyarimana, J., Humphreys, M., Posner, D. N., \& Weinstein, J. (2009). Coethnicity: Diversity and the Dilemmas of Collective Action. New York: Russell Sage Foundation.

Harris, A. S. \& Findley, M. G. (2014). Is Ethnicity Identifiable? Lessons from an Experiment in South Africa. Journal of Conflict Resolution, 58, 4-33.

Hodler, R. \& Raschky, P. A. (2014). "Regional Favoritism." Quarterly Journal of Economics, 129, 995-1033.

Hornsby, C. (2012). Kenya: A History Since Independence. London: I.B. Tauris.

Igoe, J. (2006). Becoming indigenous peoples: Difference, inequality, and the globalization of East African identity politics. African Affairs, 105, 399-420.

Kasfir, N. (1979). Explaining Ethnic Political Participation. World Politics, 31, 365-88. 
Keefer, P. (2007). Clientelism, Credibility and the Policy Choices of Young Democracies. American Journal of Political Science, 51, 804-21.

Kramon, E. \& Posner, D. N. (2013). Who Benefits from Distributive Politics? How the Outcome One Studies Affects the Answer One Gets. Perspectives on Politics, 11, 46174.

Kramon, E. \& Posner, D. N. (2016). Ethnic Favoritism in Education in Kenya. Quarterly Journal of Political Science, 11, 1-58.

Laitin, D. D. (1998). Identity in Formation: The Russian-Speaking Populations in the Near Abroad. Ithaca, NY: Cornell University Press.

Li, J. (2018). Ethnic Favoritism in Primary Education in Kenya: Effects of Coethnicity with the President. Education Economics, 26, 194-212.

Lindemann, S. (2011). Inclusive Elite Bargains and the Dilemma of Unproductive Peace: A Zambian Case Study. Third World Quarterly, 32, 1843-1869.

Mamdani, M. (1996). Citizen and Subject: Contemporary Africa and the Legacy of Late Colonialism. Princeton, NJ: Princeton University Press

Mazrui, A. A. (1980). Between Development and Decay: Anarchy, Tyranny and Progress under Idi Amin. Third World Quarterly, 2, 44-58.

Moerman, M. (1965). Who are the Lue: Ethnic Identification in a Complex Civilization. American Anthropologist, 67, 1215-1230.

Montalvo, J. G. \& Reynal-Querol, M. (2005). Ethnic Polarization, Potential Conflict, and Civil Wars. American Economic Review, 95, 796-816.

Nix, E., \& Qian, N. (2015). The Fluidity of Race: Racial Passing in the United States, 18801940. NBER Working Paper \#20828.

Osei-Hwedie, B. (1998). The Role of Ethnicity in Multi-Party Politics in Malawi and Zambia. Journal of Contemporary African Studies, 16, 227-47.

Østby, G. (2008). Polarization, Horizontal Inequalities and Violent Conflict. Journal of Peace Research, 45, 143-62. 
Padró i Miquel, G. (2007). The Control of Politicians in Divided Societies: The Politics of Fear. Review of Economic Studies, 74, 1259-74.

Posner, D. N. (2004). Measuring Ethnic Fractionalization in Africa. American Journal of Political Science, 48, 849-63.

Posner, D. N. (2005). Institutions and Ethnic Politics in Africa. New York: Cambridge University Press.

Rhoads, E. J. M. (2000). Manchus and Han: Ethnic Relations and Political Power in Late Qing and Early Republican China, 1861-1928. Seattle, WA: University of Washington Press.

Rossi, B. (2014). Migration and emancipation in West Africa's labour history: The missing links. Slavery and Abolition, 35, 23-46.

Tilly, C. (1994). States and Nationalism in Europe 1492-1992. Theory and Society, 23, 13146.

Van de Walle, N. (2003). Presidentialism and Clientalism in Africa's Emerging Party Systems. Journal of Modern African Studies, 41, 297-321.

Wakeman, F. (1985). The Great Enterprise: The Manchu Reconstruction of Imperial Order in Seventeeth Century China. Berkeley, CA: University of California Press.

Walters, L., Bittencourt, M., \& Chisadza, C. (2019). Public Infrastructure and Ethnic Favoritism: Evidence from South Africa. Mimeo, University of Pretoria. https://www.up.ac.za/media/shared/61/WP/wp 2019 49.zp175390.pdf

Wimmer, A. (2018). Nation-Building: Why Some Countries Come Together While Others Fall Apart. Princeton, NJ: Princeton University Press.

Young, M. C. (1976). The Politics of Cultural Pluralism. Madison, WI: University of Wisconsin Press.

Young, M. C. (1994). The African Colonial State in Comparative Perspective. New Haven, CT: Yale University Press. 


\section{Appendices to "The Politics of Ethnic Identity in Sub-Saharan Africa" \\ Appendix 1: Data Coding \\ 1.1. Coding Presidential Ethnic Groups}

I used a variety of secondary sources to code the President's ethnic group. In only three cases was the coding controversial, namely Liberia, Mali and Zambia. The first case involved Ellen Johnson-Sirleaf, President of Liberia between 2006 and 2018, whom I coded as Americo-Liberian despite the fact that none of her grandparents were ethnically AmericoLiberian (two were Gola, one was Kru and one was German). I did so for three reasons: 1) she was a minister in the last Americo-Liberian government of William Tolbert when he was overthrown in 1980,2$)$ both of her parents were taken in as "wards" by Americo-Liberian families, which was the historical path to assimilation into Americo-Liberian society for natives, and 3) she has light skin colour due to being 1/4 German and thus has a history of being mistaken for an Americo-Liberian of mulatto descent (cf. The Analyst 2012).25 In any case, my results are robust to recoding Johnson-Sirleaf's ethnic identity as Gola or Kru.

The second case involved Mali, where I followed Kramon and Posner (2013) and coded Alpha Oumar Konaré as mixed Bambara and Peulh, and Amadou Toumani Touré as mixed Malinke and Peulh. I assume that Dioncounda Traoré, who was interim President of Mali between 12 April 2012 and 4 September 2013, was Bambara like his clansman Moussa Traoré (President 1968-1991), although it is possible that he is actually from the Malinke ethnic group considering his birthplace in the city of Kati is on the border of the Bambara and Malinke home ethnic territories according to Murdock (1967). As with Liberia the result are robust to recoding Traoré as ethnically Malinke.

\footnotetext{
25 Mulattos were the dominant political group in Liberia from its founding in 1847 through the late $19^{\text {th }}$ century.
} 
The third case involved Zambia, specifically President Levy Mwanawasa (r. 20022008). I follow Kramon and Posner (2013) by coding his ethnicity as Lenje/Tonga; however, other sources such as Kim (2017) and various Zambian newspapers claim that his father was Lamba while his mother was Lenje. The results are robust to either coding.

\subsection{Coding Ethnic Homelands}

For many surveys the DHS provides the GPS location for each enumeration area, which would allow me to use Murdock (1967)'s data on African ethnic homelands as the ethnic homeland rather than an administrative unit. However, there are two problems with this approach. First, there is not an exact match for many of the ethnic groups by the DHS data to those listed by Murdock (1967), with the Americo-Liberians of Liberia, the Annang of Nigeria and the Kuria, Ndengereko and Zanaki of Tanzania listed in the former but not the latter, for instance. Second, GPS data is not available for 16 of the 56 surveys, which leads to a loss of 8 out of the 25 ethnic presidential transitions from the dataset, or over $1 / 4$ of all transitions (and all transitions from both Kenya and Tanzania). As such I use the administrative unit as the homeland instead.

In several countries the regions were not consistent across surveys, either due to a lack of coding by the DHS or the creation of new sub-national units over time. In the former case I overcame this problem by using DHS GPS datasets to identify the contemporary locations of all survey enumeration areas (as in Liberia and Senegal). In the latter case I was able to combine newer units with their "mother" units in order to avoid dropping surveys which did not have GPS datasets (as in Benin and Zambia). In only one case, namely Côte d'Ivoire, was I faced with the dual problems of having both a survey that was not geocoded (the 2005 round 5 survey) and an inconsistent use of regional classification (with the 1998 round 3 survey only listing regions as Abidjan, Small City and Countryside). As such I dropped the 1998 Côte d'Ivoire survey from my analysis, since I had two surveys (1994 and 
1998) conducted during the Presidency of Henri Konan Bédié (r. 1993-1999) but only one (2005) done during Laurent Gbagbo's presidency (r. 2000-2010).

\section{Additional Bibliography}

The Analyst. (2012). Nation Celebrates with Sirleaf. October 29. Monrovia.

Kim, E. K. (2017). Party Strategy in Multidimensional Competition in Africa: The Example of Zambia. Comparative Politics, 50, 21-43.

Murdock, G. P. (1967). Ethnographic Atlas. Pittsburgh: University of Pittsburgh Press. 
Table A.1: All Ethnic Political Transitions in Sub-Saharan Africa, 1986-2016 (Bold = included in DHS/MICS dataset; Italics = President was in power for less than one year)

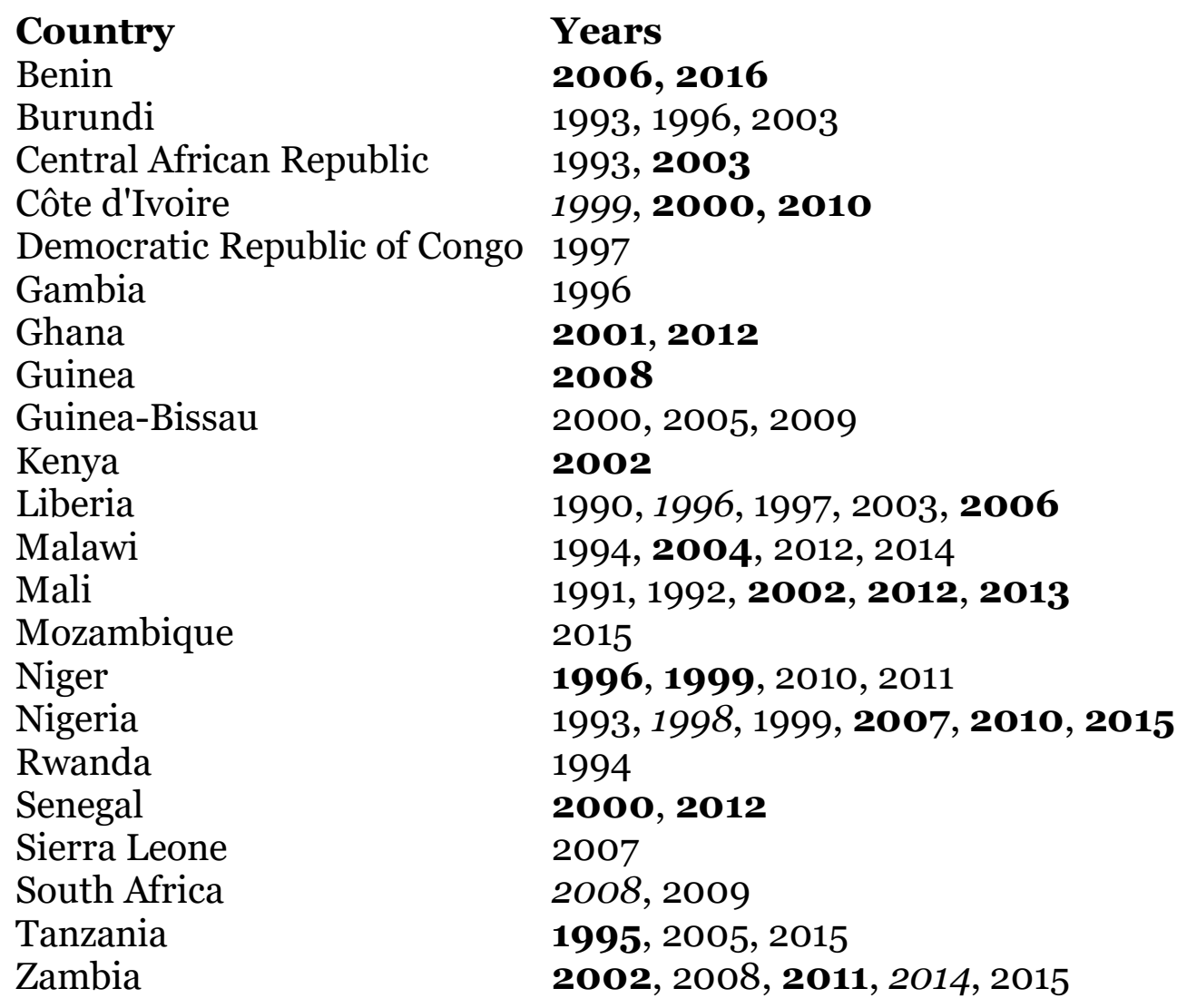

The DHS data thus covers 14 out of 22 countries for which there has been an ethnic political transition in Sub-Saharan Africa between 1986 and 2016, and 24 out of 41 ethnic political transitions within these countries for Presidents in power for more than 1 year. 
Table A.2: Correlates of Inclusion in the Dataset

Variable

British Colony

ELF (Fearon)

Mean Absolute Latitude (log)

$\mathrm{Km} 2(\log )$

GDP per capita (\$)

Polity Score

Polity Score, including

Countries w/o transitions
2+ Surveys with

Ethnic Data

0.429

0.778

2.092

12.866

625.94

1.382

0.046 o/1 Surveys with Difference of Ethnic Data Means t-test

0.419

0.680

2.132

12.289

1547.47

$-0.868$

$-0.302$
$-0.009$

$-0.098^{*}$

0.040

$-0.577$ 1260.77 $-2.250^{* *}$ $-0.348$

${ }^{*} \mathrm{p} \leq 0.1,{ }^{* *} \mathrm{p} \leq 0.05,{ }^{* * *} \mathrm{p} \leq 0.01$. The table uses World Bank GDP data. The GDP per capita and Polity scores are averages between 1986 and 2016. 
Table A.3: Ethnic/Regime Transitions in the Dataset

\begin{tabular}{|c|c|c|c|c|c|}
\hline Country & TransitionSurvey & President in Previous Survey & Ethnic Group & Subsequent President & Ethnic Group \\
\hline Benin & 20062006 & Mathieu Kérékou & Betamaribe/Somba & Thomas Boni Yayi & Yoruba \\
\hline Benin & 2016 & Thomas Boni Yayi & Yoruba & Patrice Talon & Fon \\
\hline CAR & 2006 & Ange-Félix Patassé & Sara-Kaba & François Bozizé & Gbaya \\
\hline Côte d'Ivoire & $2005^{26}$ & Henri Konan Bédié & Baoulé & Laurent Gbagbo & Bété \\
\hline Côte d'Ivoire & 2011 & Laurent Gbagbo & Bété & Alassane Ouattara & Malinké \\
\hline Ghana & 2003 & Jerry Rawlings & Ewe & John Kufuor & Akan \\
\hline Ghana & 2014 & John Atta Mills & Akan & John Mahama & Gonja/Guan \\
\hline Guinea & $2012^{27}$ & Lansana Conté & Soussou & Sékouba Konaté & Malinke \\
\hline Kenya & 1988 & Jomo Kenyatta & Kikuyu & Daniel arap Moi & Kalenjin \\
\hline Kenya & 2003 & Daniel arap Moi & Kalenjin & Mwai Kibaki & Kikuyu \\
\hline Liberia & $2006 \quad 2009^{28}$ & & Samuel Doe & Krahn & Johnson- \\
\hline Sirleaf & Americo-Liberia & & & & \\
\hline Malawi & 20042010 & Bakili Muluzi & Yao & Bingu wa Mutharika & Lomwe \\
\hline Mali & 2002 & Alpha Oumar Konaré & Bambara/Peulh & Amadou Toumani Touré & Malinke/Peulh \\
\hline Mali & $2012^{29}$ & Amadou Toumani Touré & Malinke/Peulh & Dioncounda Traoré & Bambara \\
\hline Mali & 2015 & Dioncounda Traoré & Bambara & Ibrahim Boubacar Keita & Malinke \\
\hline
\end{tabular}

${ }^{26}$ Robert Guéi (from the Yakouba or Dan ethnic group) held the Presidency of Côte d'Ivoire between 1999 and 2000 in between the 1994 and 2005 surveys.

27 Moussa Dadis Camara (from the Guerze ethnic group) and Sékouba Konate (from the Malinke ethnic group) held the Presidency of Guinea between 2008 and 2009, and between 2009 and 2010, respectively, in between the 2005 and 2012 surveys.

${ }^{28}$ Liberia saw seven heads of state (most of whom were interim) hold office in between the 1986 and 2009 surveys.

29 Amadou Sanogo (from the Bambara ethnic group) held the Presidency of Mali for less than one month in 2012 in between the 2009 and 2012 surveys. 


$\begin{array}{lllllll}\text { Niger } & 1996 & 19983^{30} & \text { Ali Saibou } & \text { Djerma } & \text { Ibrahim Baré Maïnassara } & \text { Haoussa } \\ \text { Niger } & 1999 & 2006^{3} & \text { Ibrahim Baré Maïnassara } & \text { Haoussa } & \text { Mamadou Tandja } & \text { Kanuri } \\ \text { Nigeria } & 2007 & 2008 & \text { Olusegun Obasanjo } & \text { Yoruba } & \text { Umaru Musa Yar'Adua } & \text { Fulani } \\ \text { Nigeria } & 2010 & 2013 & \text { Umaru Musa Yar'Adua } & \text { Fulani } & \text { Goodluck Jonathan } & \text { Ijaw } \\ \text { Nigeria } & \mathbf{2 0 1 5} & \mathbf{2 0 1 5} & \text { Goodluck Jonathan } & \text { Ijaw } & \text { Muhammadu Buhari } & \text { Fulani } \\ \text { Senegal } & 2000 & 2005 & \text { Abdou Diouf } & \text { Serer } & \text { Abdoulaye Wade } & \text { Wolof } \\ \text { Senegal } & 2012 & 2014 & \text { Abdoulaye Wade } & \text { Wolof } & \text { Macky Sall } & \text { Peul/Serer } \\ \text { Tanzania } & 1995 & 1996 & \text { Ali Hassan Mwinyi } & \text { Shirazi/Swahili } & \text { Benjamin Mkapa } & \text { Makonde } \\ \text { Zambia } & 2002 & 2007 & \text { Frederick Chiluba } & \text { Bemba } & \text { Levy Mwanawasa } & \text { Lenje/Tonga } \\ \text { Zambia } & 2011 & 2013^{32} & \text { Levy Mwanawaswa } & \text { Lenje/Tonga } & \text { Michael Sata } & \text { Bemba }\end{array}$

Bold indicates data is available for women only.

$3^{\circ}$ Mahamane Ousamane (from the Hausa ethnic group) held the Presidency of Niger between 1993 and 1996 in between the 1992 and 1998 surveys.

${ }^{31}$ Daouda Malam Wanké (from the Hausa ethnic group) held the Presidency of Niger for eight months in 1999 in between the 1998 and 2006 surveys.

${ }^{2}$ Rupiah Banda (from the Chewa ethnic group) held the Presidency of Zambia between 2008 and 2011 in between the 2007 and 2013 surveys. 
Table A.4: Additional Robustness Tests

(Dependent Variable: Weighted Percentage of Surveyed Population)

Sample

$\begin{array}{lll}\text { Multiple } & \text { Just Surveys Religious } & \text { Only } \\ \text { Surveys } & \text { Before/After Transitions } & \text { Men } \\ \text { Per round } & \text { Regime } & \\ & \text { Change }\end{array}$

Men and

Women
(1)
(2)
(3)
(4)
$(5)$

Co-Ethnic President*

$0.027^{* * *} \quad 0.049^{* * *}$

$0.066^{* * *}$

$0.043^{* * *}$

Autocracy

(0.010)

(0.013)

(0.025)

(0.018)

Co-Religious President

* Autocracy

Round Fixed Effects

no

yes

$-1.110$

(1.191)

yes

yes

yes

Year Fixed Effects

yes

no

no

no

no

Additional Controls from yes Table 2

Countries

14

yes

yes

yes

Surveys

70

Ethnic Groups/Religions 157

Observations 704

14

10

10

13

${ }^{*} \mathrm{p} \leq 0.1,{ }^{* *} \mathrm{p} \leq 0.05,{ }^{* * *} \mathrm{p} \leq 0.01$. The table reports robust standard errors clustered at the country- group level. The data on religious transitions used in column 3 is detailed in Table A.10. Additional controls from Table 2 include Country-Ethnicity fixed effects, home region, and the Autocracy score. Column 4 only includes data from surveys that included men aged 20-49 and with more than 2000 observations (to make it comparable to the minimum survey size among women), inasmuch as the lower and upper age limits for men range hugely across surveys. 
Table A.5: Individual Country Results

(Dependent Variable: Weighted Percentage of Surveyed Population)

Co-Ethnic Ethnic Groups Observations Mean Polity Score President $\quad(-10$ to +10$)$

Only

$\begin{array}{lll}\text { Co-Ethnic } & \text { Ethnic Groups Observations } & \begin{array}{l}\text { Mean Polity Score } \\ (-10 \text { to }+10)\end{array}\end{array}$

$\begin{array}{lllll}\text { Benin } & \begin{array}{l}-0.024^{* *} \\ (0.006)\end{array} & 8 & 40 & 6.6 \\ \text { CAR } & \begin{array}{l}0.009^{*} \\ (0.004)\end{array} & 9 & 36 & 2.0 \\ \text { Côte d'Ivoire } & \begin{array}{l}0.027^{* *} \\ (0.011)\end{array} & 18 & 54 & -0.7 \\ \text { Ghana } & \begin{array}{l}0.001 \\ (0.010)\end{array} & 7 & 35 & 5.8 \\ \text { Guinea } & \begin{array}{l}0.013 \\ (0.008)\end{array} & 6 & 24 & 0.8 \\ \text { Kenya } & \begin{array}{l}0.026^{* * *} \\ (0.003)\end{array} & 9 & 54 & 1.3 \\ \text { Liberia } & \begin{array}{l}0.014^{* *} \\ (0.006)\end{array} & 15 & 45 & 2.0 \\ \text { Malawi } & \begin{array}{l}0.0006 \\ (0.0004)\end{array} & 9 & 27 & 6.0 \\ \text { Mali } & \begin{array}{l}0.003 \\ (0.008)\end{array} & 9 & 45 & 6.0 \\ \text { Niger } & \begin{array}{l}0.020 \\ (0.013)\end{array} & 5 & 15 & 2.7 \\ \text { Nigeria } & \begin{array}{l}0.003 \\ (0.006)\end{array} & 9 & 36 & 4.8 \\ \text { Senegal } & \begin{array}{l}-0.006 \\ (0.002)\end{array} & 6 & 36 & 4.7 \\ \text { Tanzania } & \begin{array}{l}0.005^{* *} \\ (0.002)\end{array} & 30 & 60 & -3.5 \\ \text { Zambia } & \begin{array}{l}-0.006^{* *} \\ (0.002)\end{array} & 17 & 51 & 4.3 \\ & & & & \end{array}$

${ }^{*} \mathrm{p} \leq 0.1,{ }^{* *} \mathrm{p} \leq 0.05,{ }^{* * *} \mathrm{p} \leq 0.01$. Home region variable included across all regressions (but not reported here). 
Table A.6: Alternative Measures of Democracy

(Dependent Variable: Weighted Percentage of Surveyed Population)

$\begin{array}{lllll}\text { Autocracy definition } & \begin{array}{l}\text { Freedom } \\ \text { House }\end{array} & \begin{array}{l}\text { Press Freedom } \\ \text { Index }\end{array} & \begin{array}{l}\text { VDem } \\ \text { Polyarchy } \\ \text { (inverted) }\end{array} & \begin{array}{l}\text { A. \& I. (20 } \\ \text { Country-A } \\ \text { Coefficients }\end{array} \\ & (1) & (2) & (3) & (4) \\ \begin{array}{l}\text { Co-Ethnic President } \\ \quad \text { Autocracy }\end{array} & \begin{array}{l}0.007^{* * *} \\ (0.002)\end{array} & \begin{array}{l}0.028^{* *} \\ (0.012)\end{array} & \begin{array}{l}0.044^{* * *} \\ (0.013)\end{array} & \begin{array}{l}-0.017^{* * *} \\ (0.008)\end{array} \\ \begin{array}{l}\text { Ethnic Groups } \\ \begin{array}{l}\text { Countries } \\ \text { Observations }\end{array}\end{array} & 157 & 112 & 157 & 148 \\ & 14 & 12 & 14 & 13 \\ & 558 & 411 & 558 & 522\end{array}$

${ }^{*} \mathrm{p} \leq 0.1,{ }^{* *} \mathrm{p} \leq 0.05,{ }^{* * *} \mathrm{p} \leq 0.01$. All regressions include the same controls as in Table 3 , as well as the continuous measure of democracy. The Press Freedom Index data is available from 1992 onwards, thereby excluding Liberia and Tanzania from the analysis. A. \& I. (2015) = Ahlerup and Isaksson (2015), which is missing data from the Central African Republic. 
Table A.7: Sampling by Region

Dependent Variable:

\% of Survey
(weighted)

President's Ethnic Group

Home Region

Time Trend

Country-Region Fixed Effects

Countries

Regions

Observations
(1)

$-0.002$

(0.005)

\% of Survey

(weighted)

(2)

0.0009

(0.005)

yes

yes

14

136

487 yes

yes

13

119

453
(3)

0.001

(0.007)

Overall

Response

Rate

Overall

Response

Rate

(4)

$-0.001$

(0.007)

yes

yes

yes

12

104

314
12

104

314

${ }^{*} \mathrm{p} \leq 0.1,{ }^{* *} \mathrm{p} \leq 0.05,{ }^{* * *} \mathrm{p} \leq 0.01$. 
Table A.8: Secondary Interaction Results

(Dependent Variable: Weighted Percentage of Surveyed Population)
(1)
(2)
(3)
(4)
(5)
(6)
(7)
(8)
(9)

Co-Ethnic President * Autocracy

Neighboring Country has Co-Ethnic President

Co-Ethnic President *

$$
\text { Log GDP per capita }
$$

Total Years of Schooling

State Antiquity Index

ELF (Fearon 2003)

ELF (Desmet et al. 2012)

Intermarriage Rate

Access to Electricity

Access to Piped Water

\section{Countries}

Ethnic Groups

Observations

$$
\begin{aligned}
& (0.009) \\
& 0.011^{* *} \\
& (0.004)
\end{aligned}
$$$$
0.031^{* * *} \quad 0.032^{* * *} \quad 0.035^{* * *}
$$$$
\text { (0.009) }
$$

(0.009)

$0.040^{* * * *}$

$0.034^{*}$

$0.034^{* * *}$

$0.038^{* * *}$

(0.009)

(0.014)

$0.025^{*}$

$$
\begin{aligned}
& -0.004 \\
& (0.003)
\end{aligned}
$$

-0.001
$(0.001)$

0.012
$(0.014)$

0.011
(0.008)

\section{$0.020^{*}$}

(0.012)

$$
\begin{aligned}
& 0.0002 \\
& (0.019)
\end{aligned}
$$

$-0.002$

(o.013)

-0.016
(0.019)

$\begin{array}{lllllllll}14 & 14 & 12 & 13 & 14 & 14 & 12 & 12 & 14 \\ 148 & 157 & 142 & 127 & 157 & 157 & 133 & 133 & 157 \\ 522 & 552 & 489 & 498 & 558 & 558 & 385 & 447 & 527\end{array}$

${ }^{*} \mathrm{p} \leq 0.1,{ }^{* *} \mathrm{p} \leq 0.05,{ }^{* *} \mathrm{p} \leq 0.01$. All regressions include the same controls as in Table 3 as well as the non-interacted variable of interest. Additional interaction effects that were correlated with ethnic favoritism in the literature such as average taxation as a percentage of GDP, 
average revenue as a percentage of GDP, average government expenditure on education as a percentage of GDP and having a dominant religion (Franck and Rainer 2012), all yielded similar results. 
Table A.9: Zambian 2001-2002 Survey Results, by Region

$\begin{array}{llllll}\text { Dependent Variable: } & \text { Bemba } & \text { Bemba Home } & \text { Nyanja } & \text { Nyanja } & \text { Home } \\ & \text { Ethnicity } & \text { Language } & \text { Ethnicity } & \text { Language }\end{array}$
(1)
(2)
(3)
(4)

Panel A: Only Eastern, Central and Northern Provinces

$\begin{array}{lllll}\text { Post-Election } & \begin{array}{lll}-2.003^{* * *} \\ (0.377)\end{array} & \begin{array}{l}-2.427^{* * *} \\ (0.378)\end{array} & \begin{array}{l}1.221^{* * *} \\ (0.341)\end{array} & \begin{array}{l}0.338 \\ (0.250)\end{array} \\ \text { Observations } & 2282 & 2282 & 2282 & 2282\end{array}$

Panel B: Excluding Eastern, Central and Northern Provinces

$\begin{array}{lllll}\text { Post-Election } & \begin{array}{l}-0.400^{*} \\ (0.238)\end{array} & \begin{array}{l}-0.466^{*} \\ (0.252)\end{array} & \begin{array}{l}0.036 \\ (0.236)\end{array} & \begin{array}{l}-0.703 \\ (0.489)\end{array} \\ \text { Observations } & 3303 & 3303 & 3303 & 3303\end{array}$

${ }^{*} \mathrm{p} \leq 0.1,{ }^{* *} \mathrm{p} \leq 0.05,{ }^{* * *} \mathrm{p} \leq 0.01$. Additional controls include age, age squared, gender, rural residence, level of education, Catholic identification, employment status and a dummy for the home province of each group (Northern province for columns 1-2 and Eastern Province for columns 3-4). The table reports robust standard errors clustered at the enumeration area. 
Table A.10: DHS Data on Religious Political Transitions in Sub-Saharan Africa

$\begin{array}{ll}\text { Country } & \text { Mean Polity Score } \\ \text { Benin } & 6.6 \\ \text { Côte d'Ivoire } & -1.1 \\ \text { Ghana } & 5.4 \\ \text { Kenya } & 3.1 \\ \text { Madagascar } & 6.3 \\ \text { Malawi } & 5.7 \\ \text { Mozambique } & 5.0 \\ \text { Nigeria } & 0.5 \\ \text { Tanzania } & -2.2 \\ \text { Zambia } & 4.6\end{array}$

Surveys

1996, 2001, 2006, 2011, 2017

1994, 2005, 2011, 2016

1988, 1993, 2003, 2008, 2014

$1988,1993,2003,2008,2014$

1992, 1997, 2003, 2008, 2013

2000, 2010, 2015

1997, 2003, 2009, 2011

1990, 2003, 2008, 2013

1991, 1996, 2004

1996, 2007, 2013

\section{Transition(s)}

Protestant to Catholic

Catholic to Muslim

Catholic to Protestant

Protestant to Catholic

Catholic to Protestant, Protestant to Catholic

Muslim to Catholic, Catholic to Protestant

Catholic to Protestant

Muslim to Protestant

Muslim to Catholic

Protestant to Catholic

Notes: the Nigeria 2010 and 2015 DHS surveys were unusable inasmuch as they did not distinguish between Catholics and Protestant. 


\section{Figure A1: Country-Level Correlation between Ethnic Group Treated Unfairly by Government and Ethnic Switching}

(Source: Afrobarometer Round 6)

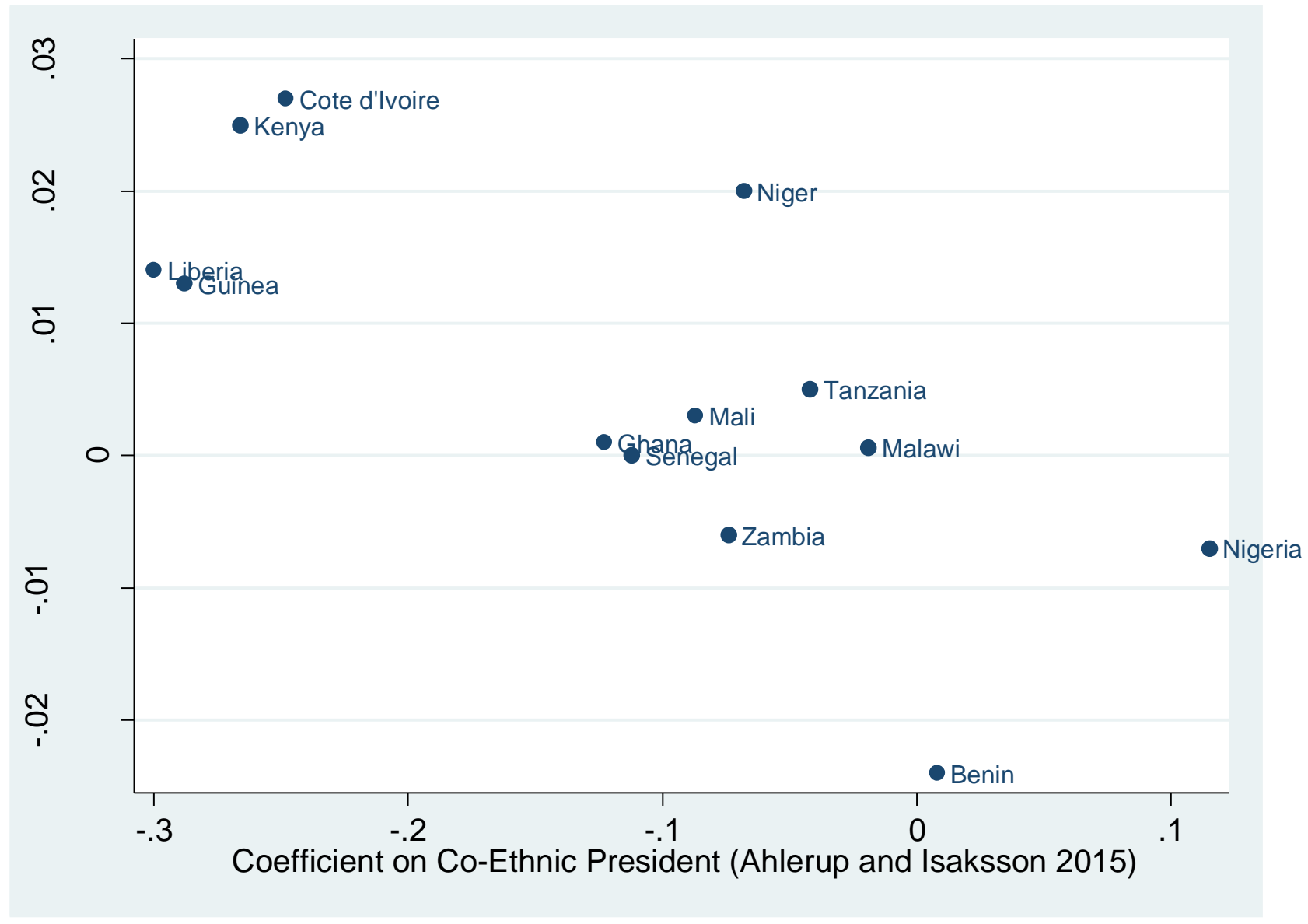

Notes: The Ahlerup and Isaksson (2015) replicated coefficients are generated by regressing the answer to the question "how often is your ethnic group unfairly treated by the government" (with "never" coded as o and "sometimes," "often" and "always" coded as 1) on whether or not the individual is a co-ethnic of the President, while controlling for age, gender and urban residence, with country-ethnic group fixed effects and standard errors clustered at the country-ethnic group level. I use data from the most recent Afrobarometer round 6 rather than the round 3 data used by Ahlerup and Isaksson (2015) as the latter does not include data from Côte d'Ivoire, Liberia and Niger. (There is missing data from the Central African Republic in all rounds.) 


\section{Figure A2: Country-Level Correlation between Regional Favoritism and}

Ethnic Switching

(Source: Hodler and Raschky 2014)

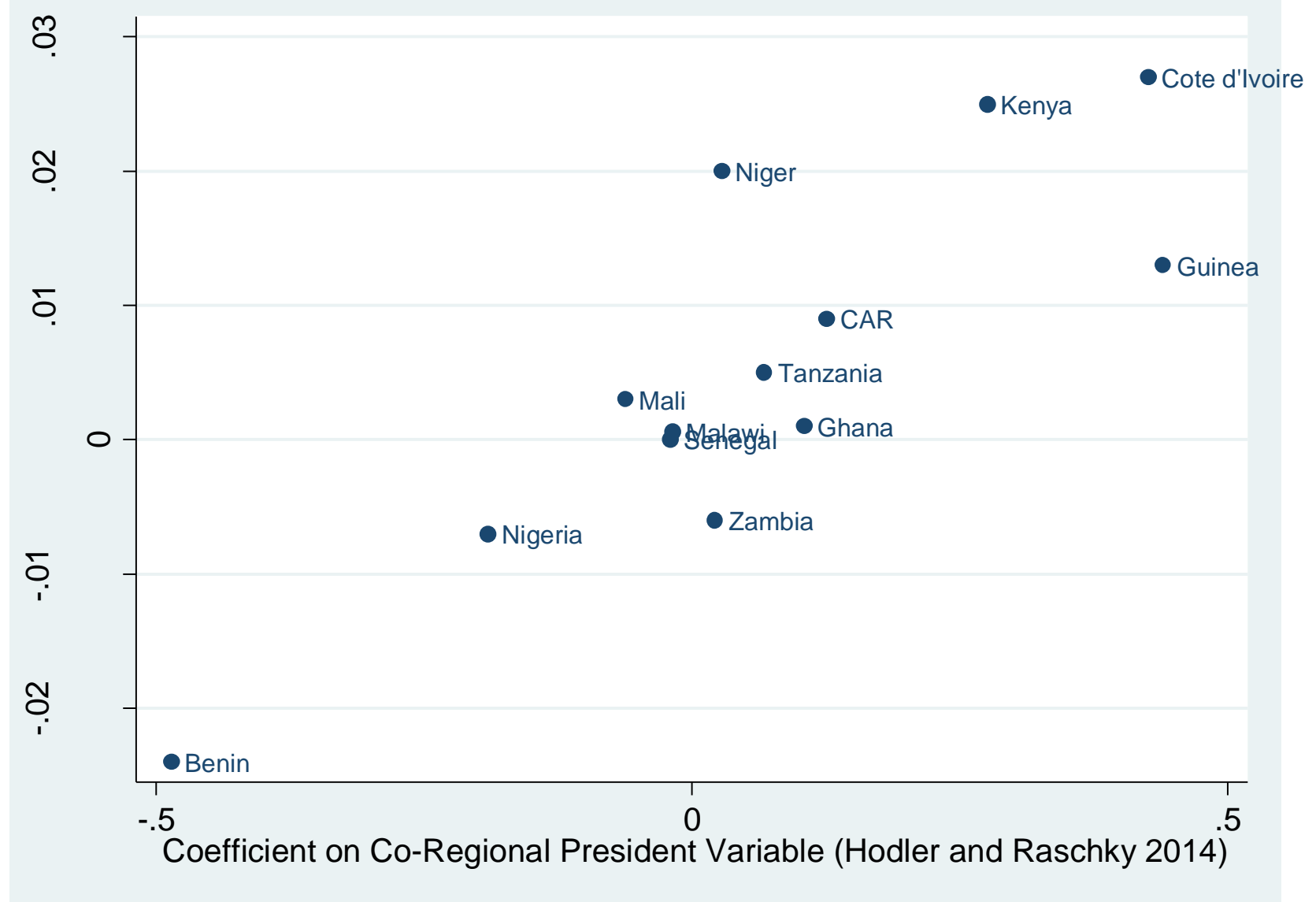

Notes: The Hodler and Raschky (2015) replicated coefficients are generated by regressing the log of nighttime light intensity on whether or not a given country-district is the birthplace of the President, while controlling for country-district and year fixed effects and standard errors clustered at the country-district level. 